\title{
The integration of young people into the labour market within the European Union: the role of institutional settings
}

Citation for published version (APA):

van der Velden, R. K. W. (2001). The integration of young people into the labour market within the European Union: the role of institutional settings. ROA. ROA Reports No. 7E https://doi.org/10.26481/umarep.200107E

Document status and date:

Published: 01/01/2001

DOI:

10.26481/umarep.200107E

Document Version:

Publisher's PDF, also known as Version of record

Please check the document version of this publication:

- A submitted manuscript is the version of the article upon submission and before peer-review. There can be important differences between the submitted version and the official published version of record.

People interested in the research are advised to contact the author for the final version of the publication, or visit the DOI to the publisher's website.

- The final author version and the galley proof are versions of the publication after peer review.

- The final published version features the final layout of the paper including the volume, issue and page numbers.

Link to publication

\footnotetext{
General rights rights.

- You may freely distribute the URL identifying the publication in the public portal. please follow below link for the End User Agreement:

www.umlib.nl/taverne-license

Take down policy

If you believe that this document breaches copyright please contact us at:

repository@maastrichtuniversity.nl

providing details and we will investigate your claim.
}

Copyright and moral rights for the publications made accessible in the public portal are retained by the authors and/or other copyright owners and it is a condition of accessing publications that users recognise and abide by the legal requirements associated with these

- Users may download and print one copy of any publication from the public portal for the purpose of private study or research.

- You may not further distribute the material or use it for any profit-making activity or commercial gain

If the publication is distributed under the terms of Article $25 \mathrm{fa}$ of the Dutch Copyright Act, indicated by the "Taverne" license above, 
The Integration of Young People into the Labour Market within the European Union: the Role of Institutional Settings

\author{
ROA-R-2001/7E
}

Rolf van der Velden

Riccardo Welters

Maarten Wolbers

Research Centre for Education and the Labour Market

Faculty of Economics and Business Administration

Maastricht University

Maastricht, November 2001 
ISBN 90-5321-319-8

Sec01.334.doc/MW 


\section{Contents}

Executive summary ii

1 Introduction 1

2 Theoretical background 5

2.1 National institutional factors related to industrial relations 5

$\begin{array}{ll}2.1 .1 & \text { Insiders versus outsiders }\end{array}$

2.1.2 Public spending on active labour market policies for youngsters 7

2.2 National institutional factors related to the education and training system 8

$\begin{array}{ll}2.2 .1 \text { Vocational specificity } & 8\end{array}$

$\begin{array}{ll}2.2 .2 \text { Standardisation and stratification } & 9\end{array}$

$\begin{array}{ll}2.2 .3 \text { Selectivity } & 10\end{array}$

3 Research design 13

3.1 Data and definitions 13

$\begin{array}{ll}3.2 \text { Key indicators } & 16\end{array}$

$\begin{array}{ll}\text { 3.3 Measuring youth labour market performance } & 17\end{array}$

4 Country differences in the labour market integration of young people 19

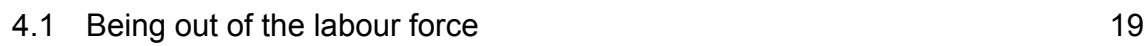

4.2 Being unemployed 22

$\begin{array}{ll}4.3 \text { Having a temporary job } & 25\end{array}$

$\begin{array}{ll}4.4 \text { Having a part-time job } & 29\end{array}$

5 The role of institutional settings 33

5.1 National institutional contexts 33

5.2 General labour market situation $\quad 36$

$\begin{array}{ll}5.3 \text { Odds of being out of the labour force } & 37\end{array}$

$\begin{array}{ll}5.4 \text { Odds of being unemployed } & 41\end{array}$

5.5 Odds of having a temporary job $\quad 45$

5.6 Odds of having a part-time job 48

6 Conclusions and discussion $\quad 51$

7 References $\quad 59$

Appendix: the interpretation of posterior means $\quad 61$ 



\section{Acknowledgement}

This study is conducted for the European Commission's Directorate-General for Employment and Social Affairs, under contract no. SOC-98-101630 05A02. The authors would like to thank Frédérique Rychener for her comments on earlier drafts of this report. 



\section{Executive summary}

The integration of young people into the labour market has been subject to a great deal of research over the last decade. This increased attention is primarily caused by the persistently high levels of youth unemployment in Europe since the eighties. Furthermore, increasing globalisation and competitiveness, in combination with rapid technological changes, have made education and training in modern societies of increasing importance in the social stratification process and as an economic growth factor. The underlying sources of problems faced by young people during the transition from school to work in different European countries are difficult to disentangle. Policy interventions can only be successful if one understands the particular features of the transition from school to work in different European education and employment structures. This raises the need for an institutional framework that helps to determine the factors affecting success and failure in the labour market integration of youngsters.

This study intends to define a set of adequate key indicators that makes it possible to evaluate the integration of young people into the labour market within the European Union. These indicators are related to differences in the institutional arrangements that constrain the school-to-work transition patterns in the Member States. The aim is to highlight similarities and differences in the integration process between the various countries and to relate these to national institutional differences.

In developing key indicators concerning the school-to-work transition, it is important that these indicators are comparable between countries and between years. This implies that structural factors affecting the integration of young people into the labour market have to be taken into account.

Firstly, the integration process depends on the speed with which the labour market absorbs school-leavers. This absorption power is influenced by national institutional differences with regard to industrial relations. Because labour market regulations differ between countries, the absorption power does too. The insider-outsider theory appears very promising and interesting in this respect. In this study, the particular interest is in the effects of wage bargaining, trade union power and employment protection legislation on the integration process. In addition, attention is paid on the effects of active youth labour market policies.

Secondly, differences related to institutional arrangements in education and training systems affect the transition from school to work. Following recent theoretical considerations, three aspects of national institutional contexts related to education and training systems are distinguished: diversity in the institutional linkage between the education/training system and the employment system, differences in the degree of standardisation and stratification in curricular/pedagogical and examination/ certification terms, and variation in the expansion of the education system.

Thirdly, labour market conditions differ between countries within the European Union. Some countries can go through a recession whereas others can be in the middle of 
an upturn at the same time. To prevent differences in the general labour market situation of countries to play a disturbing role in determining the impact of national institutional contexts of the employment and the education/training systems on the integration process of young people into the labour market, the effect of the business cycle has to be taken into account.

For the construction of key indicators, the European Community Labour Force Survey (ECLFS) data set is used. This cross-sectional data set combines the original Labour Force Surveys (LFS) as held by the individual Member States. This pooled data set, which consists of information covering the period 1992-1997, is the best one available at the moment to address the issue of the transition from school to work in Europe.

On the basis of the ECLFS data set, four key indicators are developed to describe the (lack of) integration of young people into the labour market: being out of the labour force, being unemployed, having a temporary job, and having a part-time job. Although these four indicators do not give full insight into the integration process of school-leavers, they give at least a good indication. This is due to the rather limited availability of key indicators with regard to the transition from school to work in the ECLFS data set.

The method used for estimating differences in youth labour market performance between countries is multilevel analysis. To determine cross-country differences in the labour market performance of young people, adequate statistical control for variation within countries between years and individuals is necessary. There is consensus that the use of aggregate data to control for these input characteristics leads to misspecification of the true differences. Using aggregate cross-country data will therefore produce performance scores of which the meaning and validity are highly questionable. Instead, data at the individual level is necessary. The basic idea in multilevel analysis is that individual labour market outcomes are predicted on the basis of personal characteristics (such as the level of education attained), and contextual variables (to explain differences between years and countries). For the analysis applied in this study, the individual pooled data from the ECLFS data set are matched with aggregate time series that measure differences in industrial relations, institutional contexts with regard to the education/training system and general labour market conditions between the countries of the European Union.

The results of multilevel analysis show that the labour market integration of young people within the European Union is indeed systematically structured by national institutional contexts. With regard to national institutional factors concerning labour market regulations, it is primarily the employment protection of the existing labour force that has a damaging effect on the integration process of youngsters. In countries with a less strict employment protection legislation, school-leavers find a (stable) labour market position more easily than in countries with a high strictness of employment protection. In addition, the wage bargaining structure plays a role, with centralised/co-ordinated systems performing better than decentralised/unco-ordi- 
nated ones in terms of unemployment among school-leavers. These two findings confirm empirically the supposed insider-outsider dichotomy in the labour market.

With regard to institutional characteristics of education and training systems, it is clear that the presence of an extensive dual system - as a workplace-based vocational training system - improves the transition from school to work in a country. The positive effect of having a dual system on the labour market integration of youngsters stems from the strong allocation function of the dual system: the institutionalised pathway it provides for young people to enter the labour market. The effect does not seem so much to be related to the more vocational orientation of countries with a dual system, since the results of this study show that the specificity of vocational education does not play an important role in the integration process. The stratification of the education system neither has an impact on the transition from school to work.

Furthermore, it turned out that the indicators for the measurement of youth labour market integration show quite similar results and are, therefore, coherent key indicators. Only with respect to part-time employment it seems that this labour market outcome is a less appropriate indicator. First of all, the cross-country variation regarding part-time employment could not be explained by the factors that are - to a large extent - responsible for the country differences with respect to the other indicators. Part-time employment among young people in a country is neither influenced by general labour market conditions nor by the degree of employment protection legislation and/or the provision of a dual system in that country. In addition, part-time employment is hardly correlated at the country level with the other indicators for the integration of young people into the labour market, whereas these other indicators are fairly strong interrelated. This suggests that a high percentage of part-time work in a country is not a characteristic of the youth labour market, but a more generalised feature of the labour market of that country.

Lastly, we should mention a certain limitation of this study. Due to the rather limited availability of adequate key indicators in the data set used, we could not give a complete picture of the integration process of school-leavers into the labour market. Firstly, information on wages is lacking. Secondly, job match or skill use characteristics are missing. For instance, it was not possible to determine whether the actual level of education held by school-leavers fits with the theoretical level of education requested by the job ('overeducation'). Thirdly, information on labour mobility is not available. Since school-leavers often start in jobs that do not match their education, job mobility is considerable among them. Therefore, in future research it would be very interesting to investigate whether national institutional contexts affect these other indicators of youth labour market integration. However, this kind of information requires other comparative data sources that are unfortunately not available (yet). 



\section{Introduction}

The transition from school to work has been a major research topic over the last ten years (for an overview, see Hannan and Werquin (1999) and Ryan (2001)). The main reason for this attention is the occurrence of persistently high youth unemployment rates in Europe since the eighties. A considerable proportion of young people is unemployed in the period after leaving school, and even the youngsters who immediately find a job, are often working in vulnerable positions. This makes the integration process of young people into the labour market far from smooth and the transition from school to work can therefore be characterised as a precarious and uncertain period for young people (OECD, 1998: 111). To overcome this social problem, policy makers have focused a lot of attention on the integration of young people into the labour market by means of substantial state investments to improve the transition from school to work. Originally, these investments occurred in rather indirect labour market interventions such as employment and training programmes. Only recently, more active interventions have been taken, for instance in the form of subsidised jobs.

In addition, globalisation and competitiveness have made policy makers aware that education and training - i.e. human capital growth - is of increasing importance as an economic growth factor (see the EU Commission's White Paper (1993)). Human capital determines the productivity level of the labour force. The productivity level attained in the labour market is an important factor which influences the competitiveness of a country. Especially an education/training system - as the most important provider of human capital - that wants to fulfil the requirements of the labour market, needs to take care of the level of knowledge and skills of the youth labour force, since young people are very useful to firms in need of highly qualified, new personnel. Besides that, a well-functioning education system seems vital in a labour market characterised by rapid technological changes.

The underlying sources of problems faced by young people during the transition from school to work in different European countries are difficult to disentangle. Policy interventions can only be successful if one understands the particular features of the transition from school to work in different European education and employment structures. This creates the need for an institutional framework that helps to determine the factors affecting success and failure in the labour market integration of youth. The European Commission's Directorate-General for Employment and Social Affairs entitled us to evaluate the performance of Member States with regard to the integration process of young people into the labour market. To evaluate, we introduce key indicators. These indicators are used as summary statistics for measuring the performance of a system (Tuynman and Potslethwaite, 1994; OECD 1995). In this case, the use of key indicators enables policy makers to assess differences in performance with regard to the integration of youngsters into the labour market, by enabling a systematic comparison, between countries and between years.

In this study, we aim at developing a set of key indicators that enables to evaluate the integration process of young people into the labour market. These indicators will 
be related to differences in the institutional arrangements that constrain the schoolto-work transition patterns in the Member States. The aim is to highlight similarities and differences in the integration patterns between the various countries and to relate these to national institutional differences.

Key indicators should meet three criteria. Firstly, key indicators should be a good reflection of reality at a glance, i.e. a limited number of statistics should cover the different aspects of young people's integration into the labour market. To create these indicators, we will use the European Community Labour Force Survey (ECLFS) data. The ECLFS constitutes the best available data set in this respect, because of its scale and its comparability between Member States. The ECLFS contains some of the most important indicators on young people's integration pattern, such as labour force participation, unemployment, permanency of jobs, et cetera. On the basis of this data set, we will construct the key indicators needed to describe the transition from education to work for young people within the European Union.

Secondly, key indicators that measure the transition pattern should be comparable between countries and between years. This means that we have to take into account structural factors that influence the integration process of youngsters into the labour market. A first possible source of structural factors that affect the integration of young people into the labour market arises from national institutional differences with regard to industrial relations. The integration of youngsters into the labour market (partially) depends on the speed with which the labour market absorbs school-leavers. This absorption power may be influenced by industrial relations. Because labour market regulations differ between countries, the absorption power does too. The insideroutsider theory appears very promising and interesting for our concern. For this purpose, we are particularly interested in the effects of employment protection legislation, union power and wage bargaining on the integration process. In addition, the effects of active youth labour market policies on the transition from school to work are relevant.

Whereas differences related to industrial relations influence the integration of young people into the labour market from the labour demand side, differences related to institutional arrangements in education and training systems affect the transition from school to work from the supply side. School-leavers who have passed through education systems that provide 'tailor-made' education - i.e. education in which pupils acquire a set of qualifications that match employers' needs -, are considered to be more attractive to employers to hire than others. Following recent theoretical considerations, we distinguish three aspects of national institutional contexts related to education and training systems: diversity in the institutional linkage between the education/training system and the employment system, differences in the degree of standardisation and stratification in curricular/pedagogical and examination/ certification terms, and variation in the expansion of the education system.

Labour market conditions differ between countries within the European Union. Some countries may go through a recession, whereas others can be in the middle of an upturn at the same time. Of course, macroeconomic conditions play a role with 
regard to the extent and speed of the labour market integration of school-leavers. To prevent differences in the general labour market situation playing a disturbing role in determining the impact of national institutional contexts of both the employment and the education/training system on the integration process, we have to take the effect of the business cycle into account.

Thirdly, key indicators should be interpretable not only quantitatively but also qualitatively. To be able to interpret these indicators qualitatively, we will use benchmarking tools. Benchmarking enables us to put the various results arising from the key indicators into perspective. That is, we determine differences in the youth labour market performance between countries on the basis of appropriate key indicators. 



\section{Theoretical background}

As already mentioned above, increasing globalisation and competitiveness, in combination with rapid technological changes, have made education and training in modern societies of increasing importance in the social stratification process and as an economic growth factor. The way societies deal with these developments differs. Countries vary in the institutional arrangements that constrain the transition from education to work (Kerckhoff, 1995). In this chapter, we formulate a set of hypotheses that give a provisional answer to the question how national institutional arrangements, both with regard to industrial relations and the education/training system, influence the integration of young people into the labour market within the European Union. This set of hypotheses will be empirically tested in Chapter 5 of this study, in which we link the key indicators with the national institutional contexts with regard to the employment system and the education/training system.

\subsection{National institutional factors related to industrial relations}

\subsubsection{Insiders versus outsiders}

The integration of youngsters into the labour market strongly depends on the extent to which the labour market absorbs school-leavers (OECD, 1998: Chapter 3). The insider-outsider theory appears very promising and interesting in this respect (Lindbeck and Snower, 1988). As its name indicates, this theory relies on the distinction between 'insiders' and 'outsiders'. Employed workers are insiders and unemployed workers are, in general, referred to as outsiders. However, a specific group of outsiders consists of labour market entrants (DeVreyer, Layte, Wolbers and Hussain, 2000), since school-leavers without any work experience have to compete for available jobs with those who have already gained a position on the labour market. According to the insider-outsider theory, wage bargaining takes place between insiders and employers. Outsiders play no role in this process. The main interest of insiders is to keep their wage level. The employment of outsiders has no priority. As long as the economic system is not submitted to radical changes in social institutions or a big shock (such as an oil crisis or a major war), insiders bargain so as to get the highest wage level possible without losing their employed position. As a consequence, nothing changes and outsiders remain unemployed.

The level at which wage bargaining takes place determines the strength of the insider-outsider dichotomy and, therefore, the extent to which school-leavers are integrated into the labour market. At one extreme, firms and employees can negotiate on wages at the level of the individual enterprise. In that case, the wage bargaining structure is labelled as decentralised. At the other extreme, wage bargaining is called centralised when employees and employers are organised into nationwide unions, where the rate of unionisation of both employers and employees is high and where wages are negotiated at the central level. Lastly, wage bargaining is called intermediately centralised when wage negotiations occur at industry level. 
Calmfors and Driffill (1988) have argued that the economic performance of countries is best at both extremes of centralisation degrees. Countries characterised by intermediately centralised economies, however, have to deal with larger unemployment rates. This phenomenon is known as the hump-shaped relationship between the degree of centralisation and unemployment.

The arguments for this relationship are sought in imperfectly competitive labour markets, where both the level of employment and the real wage are included in the unions' utility function. Both in decentralised and centralised wage bargaining systems, the agents involved in the bargaining process face a very adverse trade-off between the real wage and employment, but for different reasons. The trade-off is adverse for decentralised unions, because if they set a high money wage this will be passed on in the price of the firm. The price increase will lead to a substantial loss of demand for the firm's products and consequently will lead to lower employment at the firm. Together, these factors will induce unions that operate in decentralised wage bargaining systems to set moderate wage demands. In a centralised wage bargaining structure, on the other hand, high money (nominal) wages set by unions will not lead to equally high real wage increases, because of the high degree of unionisation. This high degree of unionisation will lead to high money wages throughout the whole economy and consequently to high price changes throughout the whole economy, too. Eventually, nominal wages will indeed increase, but real wages will not. The only effect that setting high money wages will have is a deterioration of the competitive position. Again, there is no incentive for unions to set high money wages.

The contrary applies to unions operating in intermediately centralised wage bargaining systems. High money wages set by unions will lead to only a limited loss of demand for the products of the firm if this firm passes on the wage increases to the product prices, because all firms within the sector have to increase their prices. The other argument which would induce unions to set moderate wage demands - i.e. high nominal wage demands will not lead to high real wage increases, because of the general price increases - does not apply or only partially applies to the intermediate case, too. Only prices within the same sector will rise, but not those in other sectors, which will make real wage increases nearly as high as nominal wage increases. Therefore, in intermediately centralised wage bargaining systems, there is indeed an incentive to set high wage demands.

In previous empirical results, however, there is little systematic evidence of a humpshaped relationship between the degree of centralisation of the wage bargaining process and the level of unemployment (OECD, 1997: Chapter 3). Instead, some authors (for example Soskice, 1990; Layard, Nickell and Jackman, 1991) challenged Calmfors and Drifill's conclusions and proposed a negative linear relationship. Their argument is that the favourable performance effects of increasing centralisation that arise from taking the macroeconomic results of any agreement on wages into consideration are stronger than the adverse effects from imperfect product market competition. In addition, Soskice (1990) concentrates on co-ordination instead of centralisation. He argues that it is not the locus of the formal wage bargaining that is 
relevant, but the degree of consensus between the agents in the collective bargaining process. In this way, co-ordination and centralisation may be seen as two different paths to achieve the same goal. Therefore, our first hypothesis is:

\section{Hypothesis 1:}

The more centralised and co-ordinated the wage bargaining structure is in a country, the more likely it is that within this country young people are integrated into the labour market.

Irrespective of the degree of centralisation/co-ordination of the wage bargaining structure, it is assumed that the degree to which workers' wages are determined by collective bargaining or the degree to which workers are unionised in a country is important with regard to unemployment. In principle, union power is insider power. Therefore, we expect that the power of unions is likely to play an important role in the integration process of youngsters into the labour market:

Hypothesis 2:

The more power unions have in a country, the less likely it is that within this country young people are integrated into the labour market.

Apart from wage bargaining, insiders negotiate about employment protection. Employment protection refers to regulations concerning both hiring and firing and is intended to reduce economic uncertainty of workers by enhancing job security (OECD, 1999: Chapter 2). In general, insiders try to increase their job security by fixing more firmly a number of employment conditions (such as period of notice, severance pay, seniority) in the law and/or collective labour agreements. Especially, seniority is a major criterion. Usually, this principle prohibits settled employees to be fired and youngsters, who are the last employees that entered the firm, will be the first to be fired if the firm needs to do so. This is called the principle of 'last in first out' (LIFO) (Oswald, 1987). For outsiders, employment protection tends to trap them in long-term unemployment or in an unstable position shifting between unemployment and temporary jobs. This is especially true for school-leavers. From this point of view, employment protection legislation undermines the chances of getting a stable labour market position for young people. This leads to the following hypothesis:

Hypothesis 3:

The stricter the employment protection legislation is in a country, the less likely it is that within this country young people are integrated into the labour market.

\subsubsection{Public spending on active labour market policies for youngsters}

Being an unemployed outsider can have permanent effects, since unemployment duration is negatively correlated with reemployment probabilities (Devine and Kiefer, 1991; Sprengers, 1992; Wolbers, 2000). There are several explanations for this relationship. First of all, there is the hypothesis that the decay of human capital during unemployment spells decreases the reemployment probabilities of long-term unemployed (Bean, 1994). The longer individuals stay out of employment, the more 
their skills deteriorate, and the higher the costs will be for future employers to refresh these skills. A second explanation is formulated in the search motivation hypothesis (Layard and Nickell, 1986). This hypothesis states that the duration of unemployment spells affects the motivation and morale of the unemployed negatively. Getting rejected several times at job applications decreases the motivation to continue to search for jobs and breaks down self-confidence, which is needed to be successful at job applications. Others (for example Vishwanath, 1989) point out that the negative relationship between unemployment duration and reemployment probabilities origins from firm behaviour. That is, employers use the employment records of applicants as a screening device. Because employers lack exact information about applicants or it is too costly to gather this information, employers introduce indicators to select between the available employees. One of these indicators is unemployment duration.

Hence, to tackle the problem of (long-term) unemployment, unemployed outsiders need help to regain employment. Since the early nineties, this help has come from government intervention by means of active labour market policies. Governments throughout Europe introduced policies to help the long-term unemployed get back into the labour market, varying from teaching the unemployed how to write application letters to actually subsidising employment places for them. This to restore their self-confidence, or to refresh their human capital. The fact that youth unemployment rates are structurally higher than general unemployment rates and the lack of work experience of youngsters, have induced many governments to aim active labour market policies especially at them (Calmfors, 1994). The effects of active labour market policies on the integration process of youngsters into the labour market can not be said to be obvious beforehand, since important active policies possibly are a sign that there is an integration problem. But, as soon as we take the general labour market situation of a country into account, it is expected that the help youngsters get from the government will improve their job prospects either directly when they get a subsidised job or indirectly when they are supported by the government at application training sessions. So:

Hypothesis 4:

The more active labour market policies for youngsters are in a country, the more likely it is that within this country young people are integrated into the labour market.

\subsection{National institutional factors related to the education and training system}

\subsubsection{Vocational specificity}

Apart from national differences related to labour market regulations, cross-country variation with regard to institutional arrangements in education and training systems affect the integration process of young people into the labour market. First of all, countries differ in the extent to which there is an institutional link between the education and training system on the one hand and the employment system on the other (Maurice, Sellier and Silvestre, 1982; Hannan, Raffe and Smyth, 1997; Müller and Shavit, 1998). Basically, this debate refers to the extent to which education systems differentiate between academic and vocational education. Some countries 
offer mainly general education. In such countries, education is weakly related to the workplace and vocational training is primarily obtained on the job. In other countries, occupation-specific skills are taught in the education and training system. Here, the link between the education/training system and the employment system is strong. The way in which this close link between the education/training system and the employment system is institutionalised, may differ. In some cases, the teaching of vocational skills is shared between vocational schools and the workplace, such as in the apprenticeship systems in Germany and surrounding countries ('dual system'). In other cases, however, the provision of vocational skills is primarily school-based.

In vocational programmes that are mainly occupation-specific - irrespective of how these programmes are institutionalised in the education system -, school-leavers have few transferable skills, which prepares them for a few, particular jobs. For employers these school-leavers are very attractive to hire, since the curricula of the vocational programmes already supply them the skills required for the job, which reduces the training costs for employers. Consequently, it is expected that in countries that provide a differentiated system of vocational education, the association between education and labour market outcomes is more tightened, and, subsequently, young people are more easily integrated into the labour market than in countries that offer primarily general education. This leads to the following hypothesis:

Hypothesis 5:

The more vocational specific the education system is within a country, the more likely it is that within this country young people are integrated into the labour market.

\subsubsection{Standardisation and stratification}

The school-to-work transition in countries differs also according to the standardisation of educational provisions and the stratification of educational opportunities of the education system (Allmendinger, 1989; Müller and Shavit, 1998). Standardisation concerns the degree to which the quality of education meets the same nationwide standards - for example with regard to teacher training, school budgets, curricula and uniformity of examination/certification terms. Stratification has to do with the extent and form of tracking at the secondary educational level (see Müller and Shavit, 1998: 50). In highly stratified education systems, pupils are divided into separate tracks very early in their educational careers. Furthermore, in these systems it is difficult to switch between tracks, since the tracks are too diverse. On the other hand, in countries characterised by a low degree of stratification, the diversity between different tracks is limited, which results in high mobility between tracks.

It is assumed that the relationship between the educational qualifications and labour market outcomes of individuals is more tightened in countries that have a highly standardised and stratified education system. The reason for it is that high standardisation and stratification make screening by employers easier. High standardisation makes the qualities of school-leavers simple to interprete and 
compare. High stratification leads to school-leavers having specific skills. Once again, this makes screening by employers easier, because in that situation employers know exactly what kind of school-leaver they need to accept for the specific vacancy they have. In the absence of high standardisation and high stratification, it will be more difficult for employers to screen the best qualified individual for their vacancies. Therefore, it is expected that a high degree of standardisation and stratification of the education system facilitates the integration process of young people into the labour market. Since in all European countries the education/training systems are highly standardised (Hannan et al., 1999; Müller and Shavit, 1998), we only formulate a hypothesis with respect to the stratification of the education system:

\section{Hypothesis 6:}

The more stratified the education system is within a country, the more likely it is that within this country young people are integrated into the labour market

\subsubsection{Selectivity}

Lastly, the selectivity of the education system affects transition processes from school to work. In this study, selectivity refers to (explicit state policies to) expand or limit the education system. In general, the educational participation has grown everywhere in Europe in recent decades, but from different starting points, in different ways, and with different results (Müller and Wolbers, 1999). The educational growth has been driven by various considerations. First of all, the increase in educational participation has been ideologically desired in order to reduce the unequal distribution of educational attainment between social groups (Shavit and Blossfeld, 1993). Secondly, due to rapid technological changes, more and more occupations on the labour market require higher skill levels (Denison, 1962). Thirdly, the rapid educational expansion has been an answer to recent social problems, such as youth unemployment, that keep young people out of the labour force - and in the education system - as long as possible (Hannan and Werquin, 1999).

In order to enhance educational expansion, institutional reforms of the education system have been implemented almost everywhere. It is assumed that the existing national traditions in the set-up of educational institutions and in the provision of education has affected the course of educational reforms and, subsequently, the degree of educational expansion (Müller and Wolbers, 1999: 20). In particular, the (non)existence of an established tradition of vocational education has determined the course of reforms. Especially in countries that have no tradition of vocational orientation in secondary education, the need and pressure for an extensive system of tertiary education are large, and for these countries one should therefore assume a strong growth in educational participation on the tertiary level.

Excessive educational expansion has detrimental consequences for labour market outcomes (Boudon, 1974). At the level of individuals, it forces young people to obtain ever more and higher levels of education, just in order to stay in a favourable position in the job queue (Thurow, 1975). At the societal level, high enrolment rates in tertiary 
education may lead to credential inflation. That is, if there are more highly educated school-leavers than the labour market can absorb, the labour market value of credentials declines (Brauns, Müller and Steinmann, 1997; Gangl and Brauns, 1999; Wolbers, De Graaf and Ultee, 2001). In that situation, a number of highly educated individuals has to accept jobs for which the required level of education is lower than the actual attained level ('overeducation'). In addition, the oversupply of highly educated school-leavers may lead to unemployment or employment exclusion among them, especially among the least qualified. Therefore, it is expected that a little selective education system, characterised by a strong educational participation in particular on the tertiary level, hinders the integration of youngsters into the labour market. Or formulated the other way around:

Hypothesis 7:

The more selective the education system is in a country, the more likely it is that within this country young people are integrated into the labour market. 



\section{Research design}

\subsection{Data and definitions}

For the purpose of this study, we use the European Community Labour Force Survey (ECLFS) data set as a means to construct the key indicators. This cross-sectional data set is a combination of the original Labour Force Surveys (LFS) as held by the individual Member States. Together they form the ECLFS data set, which is the best available data set for the moment to address the issue of the transition from education to work in Europe. The data set is attractive for the large sample size, the standardised survey design and the wide range of characteristics related to current labour market participation and employment. The ECLFS is an annual data set and in this study we make use of data collected during spring time in the period 1992-1997 (due to their recent membership of the European Union, we only have information for Austria, Finland and Sweden about the last three years).

To describe the transition from education to work, we have to define school-leavers. Since the ECLFS data set is a cross-sectional data set describing current labour market participation, individual trajectories into the labour market are not captured by the data. In this study, therefore, we adopt an indirect approach to identify schoolleavers. First, we know the current employment status of all respondents. Besides that, in the available data set a retrospective question is included asking the respondent to give his/her employment status one year before. By combining the information originating from these two questions, we distil school-leavers out of the total labour force.

A drawback of this approach is that is does not per se follow that the respondents in question have permanently left initial education. It might well be that youngsters leave the education system temporally and return later. Consequently, some individuals that are considered here as school-leavers are not school-leavers in the strict sense. More important, there is a rather large proportion of youngsters combining schooling and paid employment (Welters and Wolbers, 1999). Firstly, in the ECLFS data set, apprentices are not counted as being in education, but are counted as employed. This implies that countries such as Austria, Germany and Denmark, where the apprenticeship system is quantitatively spoken well-established, tend to show higher employment probabilities due to the definition of school-leavers used here. Secondly, the ECLFS data set is based on regular ILO conventions and definitions about the labour force (ILO, 1990). This implies that working students are counted as participating in the labour force. Since there are cross-country differences with regard to working students (especially in the Scandinavian countries, the Netherlands, and the United Kingdom, a relatively large proportion of students have a job) this might bias the employment probabilities between countries.

We distinguish between two groups of school-leavers: recent and less recent schoolleavers. This distinction is made, because the two groups are at different stages of the transition process, which surely has consequences for the extent to which the groups are integrated into the labour market. A recent school-leaver is defined as 
follows: he or she who was a pupil or a student in initial education or training one year before the survey and who at the time of the survey no longer is a pupil or student. To define the group of less recent school-leavers, we use the typical graduation age of students, which is the average age of the group of recent schoolleavers during the survey minus one year (because he/she finished school one year earlier). We compute this average graduation age for each educational level and for each country. Taking this graduation age into account, we define a less recent school-leaver as follows: he or she who, given his or her educational level and country, is aged between one and five years older than the graduation age of a school-leaver having the same education level and living in the same country. This definition implies that we compare throughout the Member States individuals who have (potentially) equal labour market experience, which is of crucial importance if we want to compare differences in the integration process of youngsters into the labour market between the countries.

The differentiation of the various kinds of qualification levels and the identification of similar levels across countries constitute a difficult task, because of the different structures of the education systems. In particular, it is problematic to establish equivalencies among different tertiary level certificates in different countries. Some countries classify certain programmes as secondary level education, whereas others regard them as tertiary level education. For the current analysis therefore, we use a broad rather than a narrow definition of educational levels. We distinguish three educational levels, namely the lower, middle and upper part of the educational range, based on the seven-level International Standard Classification of Education (ISCED) (UNESCO, 1975). The first group consists of persons with a basic education (often compulsory education) up to a lower secondary education at most (ISCED 0-2). The second group consists of youngsters having attained maximally upper secondary education (ISCED 3). The third group is made up of individuals with all kinds of tertiary education (non-university tertiary education as well as university-based tertiary education) (ISCED 5-7).

Table 3.1 shows the average graduation ages of school-leavers for each level of education and each country. The average graduation age of school-leavers who finished ISCED0-2 level at most within the European Union is 15. The differences between the Member States are rather small. In some countries, especially in Belgium and Sweden, this graduation age is higher. The lowest graduation age for the attainment of lower qualifications can be found in Ireland and the United Kingdom. The average graduation age of youngsters who successfully finish an intermediate educational level (ISCED3) is 19. The graduation age in Germany, Finland and Sweden is two years above the European average. The lowest graduation age for youngsters with intermediate education levels can be found in the British Islands. There, the average graduation age is 18 years old. The differences between countries' graduation ages are largest for tertiary education (ISCED5-7). The average graduation age at which youngsters obtain their degree in tertiary education is 23. In Germany, Denmark and Finland, this graduation age is substantially higher with 26 years of age. Also in Austria and Italy, tertiary education is attained at a relatively late age (25 years). In Belgium, Ireland and the United 
Kingdom, on the other hand, the attainment of tertiary education takes place at a rather young age. In these countries, youngsters on average obtain their degree in tertiary education when they are aged 21 or 22.

Table 3.1

Average graduation ages, by educational level and country

\begin{tabular}{llll}
\hline Country & $\begin{array}{l}\text { ISCED0-2 } \\
\text { years }\end{array}$ & $\begin{array}{l}\text { ISCED3 } \\
\text { years }\end{array}$ & $\begin{array}{l}\text { ISCED5-7 } \\
\text { years }\end{array}$ \\
\hline European Union (EU) & 15 & 19 & 23 \\
Austria (AT) & 16 & 20 & 25 \\
Belgium (BE) & 18 & 20 & 22 \\
Germany (DE) & 17 & 21 & 26 \\
Denmark (DK) & 16 & 20 & 26 \\
Spain (ES) & 16 & 19 & 23 \\
Finland (FI) & 16 & 21 & 26 \\
France (FR) & 17 & 20 & 23 \\
Greece (GR) & 16 & 19 & 21 \\
Ireland (IE) & 15 & 18 & 23 \\
Italy (IT) & 16 & 20 & 24 \\
Luxembourg (LU) & 18 & 20 & 23 \\
Netherlands (NL) & 16 & 20 & 24 \\
Portugal (PT) & 17 & 20 & 22 \\
Sweden (SE) & 18 & 21 & \\
United Kingdom (UK) & 15 & 18 & \\
& & & 23 \\
\hline Source: POO)d & & & \\
\hline
\end{tabular}

Source: pooled ECLFS-data 1992-1997

Table 3.2 displays the educational distribution of school-leavers within the European Union. This table shows that throughout the European Union nearly 50 percent of all school-leavers have attained a diploma at the intermediate level (ISCED3). The two other educational levels have equal shares of about one quarter each. However, the differences in educational attainment between the countries are substantial. The proportion of school-leavers that has attained only lower qualifications (ISCED0-2) is relatively small in countries such as Austria, Belgium, Germany, France and Sweden. In these countries, less than 20 percent of all school-leavers have attained no more than lower qualifications. In the South European countries, but also in Luxembourg and the United Kingdom, on the other hand, a high proportion of low educated school-leavers can be found. Portugal has the top position, with more than two thirds of all school-leavers having only basic education.

Countries that have the highest shares of school-leavers with qualifications at the intermediate level (ISCED3) are Austria, Germany and Sweden. These are three countries that have small proportions of low educated school-leavers. Moreover, these countries have an elaborate system of vocational education at the intermediate level, which prepares youngsters very well for their entrance into the labour market. Low shares of intermediate educated school-leavers can be found in Spain, Portugal and the United Kingdom. Not surprisingly, these countries have high shares of low educated youngsters. 
With regard to the attainment of tertiary education (ISCED5-7), there are large differences between countries as well. The lowest proportions of high educated school-leavers are found in Austria, Italy and Portugal, where no more than 10 percent of all youngsters have left school with a degree at the tertiary level. On the other hand, countries such as Spain, Belgium, Ireland and France experienced an enormous expansion of higher education. Around one third of all school-leavers in these countries enters the labour market with a degree in tertiary education.

Table 3.2

Educational attainment of school-leavers, by country

\begin{tabular}{|c|c|c|c|}
\hline Country & $\begin{array}{l}\text { ISCEDO-2 } \\
\%\end{array}$ & $\begin{array}{l}\text { ISCED3 } \\
\%\end{array}$ & $\begin{array}{c}\text { ISCED5-7 } \\
\%\end{array}$ \\
\hline European Union & 28 & 48 & 24 \\
\hline Austria & 12 & 77 & 11 \\
\hline Belgium & 19 & 47 & 34 \\
\hline Germany & 9 & 65 & 26 \\
\hline Denmark & 18 & 57 & 25 \\
\hline Spain & 42 & 24 & 34 \\
\hline Finland & 25 & 52 & 23 \\
\hline France & 21 & 49 & 30 \\
\hline Greece & 25 & 52 & 23 \\
\hline Ireland & 29 & 42 & 29 \\
\hline Italy & 39 & 51 & 10 \\
\hline Luxembourg & 43 & 33 & 24 \\
\hline Netherlands & 17 & 58 & 25 \\
\hline Portugal & 68 & 20 & 12 \\
\hline Sweden & 17 & 60 & 23 \\
\hline United Kingdom & 43 & 33 & 24 \\
\hline
\end{tabular}

Source: pooled ECLFS-data 1992-1997

\subsection{Key indicators}

On the basis of the ECLFS data set, we use four key indicators to describe the (lack of) integration of young people into the labour market:

- $\quad$ being out of the labour force;

- $\quad$ being unemployed;

- $\quad$ having a temporary job;

- $\quad$ having a part-time job.

Although these four indicators do not give a full insight into the integration process of school-leavers into the labour market, they give at least a good reflection. This is due to the rather limited availability of key indicators with regard to the transition from school to work in the ECLFS data set. Firstly, information on wages is lacking. Secondly, job match or skill use characteristics are missing. For instance, it cannot be determined whether the actual level of education held by school-leavers fits with the theoretical level of education requested by the job ('overeducation'). Thirdly, information on labour mobility is not available. Since school-leavers often start in jobs that do not match their education, job mobility is considerable among school-leavers. 
As mentioned above, the ECLFS data set follows ILO definitions. According to this definition, the labour force consists of any individuals who did paid work (even for as little as one hour) at the time of the survey, or who were not working but had a job from which the person was absent at the time of the survey. In addition, any individual who was out of employment, who was a conscript on compulsory military or community service, or who had other reasons for being out of employment, but who was looking for work and who could start working within two weeks, is included in the labour force. The unemployed labour force is defined as those individuals who are out of employment, but who are looking for employment and could start working within two weeks if they found a job. Unemployment rates are computed as the proportion of unemployed in the total labour force.

The permanency of a job is measured by making the distinction between permanent and temporary jobs. A temporary job refers to a job that is not permanent or to a job with a work contract of limited duration. The full-time/part-time distinction is based on the subjective evaluation of the respondent and not on the number of hours actually worked.

\subsection{Measuring youth labour market performance}

If one wants to assess whether the integration of young people into the labour market differs between countries, two problems arise. Firstly, most research on crosscountry differences in the performance of the labour market uses aggregate 'gross' statistics. However, countries constitute merely a 'contextual' variable when explaining the integration process of young people. The aim is to assess the overall country effect against other individual level variables, such as the level of education. Looking at aggregate 'gross' indicators may well overestimate the 'true' betweencountry variation, because part of these gross differences reflect variation between individual characteristics within countries.

Secondly, the interest is in the more stable between-country variation. However, part of the differences between countries vary from year to year. These reflect variation between countries in the business cycle or other 'temporary' causes of cross-country differences. In an analysis of differences between countries, one would like to focus on the more 'stable' differences between the countries.

The method used for estimating differences in youth labour market performance between countries can improve significantly from recent developments in statistical theories, most noticeable the so-called multilevel statistical models (Bryk and Raudenbush, 1992; Goldstein, 1995; Longford, 1993). In this case of measuring cross-country differences in the labour market performance of young people, there is a need for adequate statistical control for variation within countries between years and individuals. There is consensus that the use of aggregate data to control for these input characteristics will lead to misspecification of the true differences. Using aggregate cross-country data will therefore lead to performance scores of which the meaning and validity are highly questionable. Instead, data at an individual level is necessary. The basic idea in the multilevel approach is that individual labour market 
outcomes are predicted on the basis of their background characteristics (such as the level of education attained), as well as contextual variables (to explain differences between years and countries).

The multilevel model also fulfils the requirement with respect to the data. The time span of the data that are used for this study is relatively short: the available ECLFS data set covers only the period 1992-1997. Therefore, it is not possible to estimate separate models for each country. Due to the structure of the multilevel model, however, it is possible to pool the data. Since in that case more data are available, the statistical reliability of the estimations will improve.

In the first stage, we start with a description of between country differences in the integration process of young people into the labour market (Chapter 4). In the second stage, we try to explain these gross differences found between the various countries by taking into account the effects of industrial relations, institutional contexts with regard to the education/training system, and general labour market conditions (Chapter 5). This gives us insight in the true performance of youth labour markets. For this multilevel analysis, the individual pooled data from the ECLFS data set are matched with aggregate timeseries referring to differences in industrial relations, institutional contexts with regard to the education/training system and general labour market conditions between the various Member States. These timeseries are based on published national statistics. 


\section{Country differences in the labour market integration of young people}

The aim of this chapter is to describe cross-country differences in the integration process of young people into the labour market using the four key indicators as defined in the previous chapter. In fact, the figures that are shown here represent differences in the gross performance of youth labour markets. In the description, we break the results down by type of school-leaver, level of education and gender. These three individual characteristics are human capital factors that will be controlled for in the subsequent analysis. All three variables will have considerable effects on the integration process of young people into the labour market. In general, we expect that less recent, higher educated and male school-leavers are more integrated into the labour market than recent, lower educated and female school-leavers.

\subsection{Being out of the labour force}

We start with presenting results concerning the labour force participation of schoolleavers. Figure 4.1 shows the proportion of young people that are not in the labour force after they left school. The rate of inactivity is highest in Finland, shortly followed by Ireland and the United Kingdom. In these countries, between 20 and 25 percent of all school-leavers do not participate in the labour force. In the Netherlands, the proportion of inactive school-leavers is lowest (only eight percent). Also in Austria, Luxembourg, Belgium, Germany and Denmark, the percentage of school-leavers being out of the labour market is relatively low. All other countries show proportions around the European Union average of 15 percent of inactivity among schoolleavers.

Figure 4.1

Share of school-leavers being out of the labour force, by country

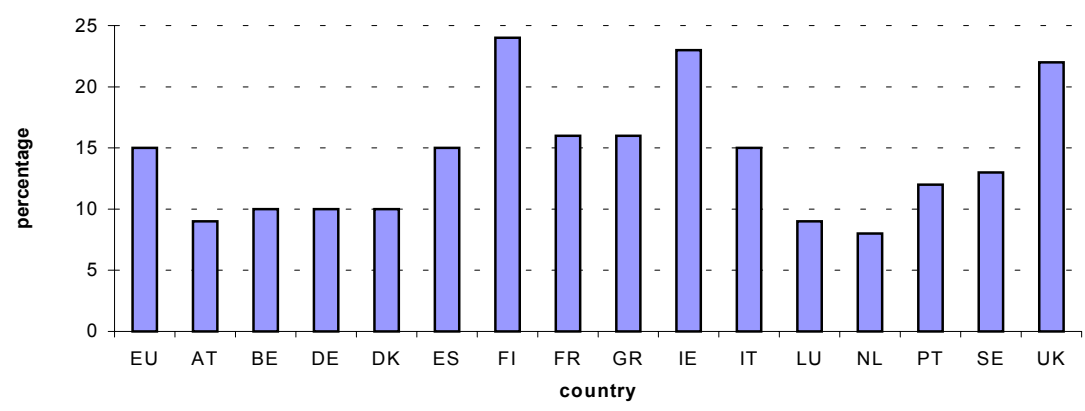

Source: pooled ECLFS-data 1992-1997 
As expected, recent school-leavers have a higher probability of being out of the labour force than less recent school-leavers (see Table 4.1). On average, the share of recent school-leavers being out of the labour market is 30 percent, whereas 11 percent of all less recent school-leavers is inactive. The corresponding odds ratio is $3.47((30 / 70) /(11 / 89))$, which means that the odds of being inactive versus active for recent school-leavers is almost three-and-a-half times higher than the odds of being inactive versus active for less recent school-leavers. This clearly indicates that the two groups of school-leavers find themselves at different stages of the integration process. The differences are largest in Ireland and the United Kingdom. This large difference is totally explained by the difficulties that recent school-leavers have in both countries to find a position in the labour force (employed or unemployed). For this type of school-leavers, the share of inactive individuals is around half, which is considerably higher than the average of 30 percent within the European Union as a whole. For less recent school-leavers in Ireland and the United Kingdom, on the other hand, the probability of being out of the labour force is below average. In Germany, the variation in inactivity between the two types of school-leavers is smallest. It seems that this has something to do with the existence of the dual system in this country, since in other countries with an apprenticeship system, such as the Netherlands, Luxembourg and Denmark, differences in the probability of being out of the labour force between recent and less recent school-leavers are relatively small as well. For Austria, however, this explanation does not seem to work. Although in this country there is an extensive system of apprenticeships, the variation with regard to inactivity is larger than in the other countries with an apprenticeship system.

Table 4.1

Differences in shares of being out of the labour force, by type of school-leaver and country

\begin{tabular}{lccc}
\hline Country & $\begin{array}{c}\text { recent } \\
\text { school-leavers } \\
\%\end{array}$ & $\begin{array}{c}\text { less recent } \\
\text { school-leavers } \\
\%\end{array}$ & odds ratio \\
\hline European Union & & & \\
Austria & 30 & 11 & 3.47 \\
Belgium & & & \\
Germany & 22 & 7 & 3.75 \\
Denmark & 17 & 9 & 2.07 \\
Spain & 13 & 10 & 1.34 \\
Finland & 16 & 7 & 2.53 \\
France & 24 & 13 & 2.11 \\
Greece & 37 & 14 & 3.61 \\
Ireland & 30 & 13 & 2.87 \\
Italy & 22 & 15 & 14.60 \\
Luxembourg & 53 & 7 & 2.23 \\
Netherlands & 25 & 13 & 1.87 \\
Portugal & 14 & 8 & 1.99 \\
Sweden & 13 & 7 & 1.90 \\
United Kingdom & 19 & 11 & 2.99 \\
& 27 & 11 & 11.05 \\
\hline Source: & 49 & 8 & \\
\hline
\end{tabular}

Source: pooled ECLFS-data 1992-1997 
Table 4.2 shows that, without any exception, lower educated school-leavers are more likely to be out of the labour force than higher educated. In the European Union as a whole, 24 percent of the lower qualified (ISCED0-2) is inactive, 12 percent of the intermediate educated (ISCED3), and eight percent of the school-leavers with a degree in higher education (ISCED5-7). Again, in the United Kingdom and Ireland the effect is strongest. In these two countries, the odds ratio for the contrast between ISCED0-2 and ISCED5-7 is 12.67 and 10.87 respectively. Germany and the Netherlands, on the other hand, show the smallest variation between levels of education.

Table 4.2

Differences in shares of being out of the labour force, by educational level and country

\begin{tabular}{lcccc}
\hline Country & $\begin{array}{c}\text { ISCED0-2 } \\
\%\end{array}$ & $\begin{array}{c}\text { ISCED3 } \\
\%\end{array}$ & $\begin{array}{c}\text { ISCED5-7 } \\
\%\end{array}$ & odds ratio $^{\text {a }}$ \\
& & & & \\
\hline European Union & 24 & 12 & 8 & 3.63 \\
Austria & 13 & 8 & 6 & 2.34 \\
Belgium & 21 & 9 & 5 & 5.05 \\
Germany & 11 & 11 & 6 & 1.94 \\
Denmark & 13 & 9 & 5 & 2.84 \\
Spain & 21 & 15 & 8 & 3.06 \\
Finland & 38 & 22 & 10 & 5.52 \\
France & 24 & 15 & 12 & 2.32 \\
Greece & 25 & 15 & 8 & 3.83 \\
Ireland & 45 & 19 & 7 & 10.87 \\
Italy & 22 & 11 & 8 & 3.24 \\
Luxembourg & 13 & 5 & 5 & 2.84 \\
Netherlands & 10 & 8 & 6 & 1.74 \\
Portugal & 15 & 10 & 3 & 5.71 \\
Sweden & 19 & 14 & 8 & 2.70 \\
United Kingdom & 40 & 10 & 5 & 12.67 \\
& & & & \\
\hline Soure: & 19 & & & \\
\hline
\end{tabular}

Source: pooled ECLFS-data 1992-1997

a: ISCED0-2 versus ISCED5-7

Differences in inactivity rates between men and women are presented in Table 4.3. Overall, there is a very weak association between gender and the likelihood of being out of the labour force. Within the European Union, 15 percent of all female schoolleavers is not participating in the labour force, whereas the corresponding percentage among male school-leavers is 14 percent. However, there is some variation in gender differences between countries. Luxembourg and Greece show the largest gender difference with regard to inactivity (odds ratio's are 4.24 and 2.69, respectively). In all other countries, the odds ratio's are less than 1.5. Finally, in Austria, Spain, Finland, France and Portugal, male school-leavers are slightly more often out of the labour force than their female counterparts. The opposite findings for these countries are rather restricted as well. 
Table 4.3

Differences in shares of being out of the labour force, by gender and country

\begin{tabular}{lccc}
\hline Country & $\begin{array}{c}\text { women } \\
\%\end{array}$ & $\begin{array}{c}\text { men } \\
\%\end{array}$ & odds ratio \\
\hline European Union & 15 & 14 & 1.08 \\
Austria & & & \\
Belgium & 8 & 9 & 0.88 \\
Germany & 11 & 8 & 1.42 \\
Denmark & 11 & 9 & 1.25 \\
Spain & 11 & 9 & 1.25 \\
Finland & 13 & 17 & 0.73 \\
France & 24 & 25 & 0.95 \\
Greece & 15 & 18 & 0.80 \\
Ireland & 21 & 9 & 2.69 \\
Italy & 25 & 21 & 1.25 \\
Luxembourg & 16 & 14 & 1.17 \\
Netherlands & 15 & 4 & 4.24 \\
Portugal & 9 & 7 & 1.31 \\
Sweden & 12 & 13 & 0.91 \\
United Kingdom & 14 & 12 & 1.19 \\
& 25 & 19 & 1.42 \\
\hline Source: pooled ECLFS-data $1992-1997$ & & & \\
\hline
\end{tabular}

Source: pooled ECLFS-data 1992-1997

\subsection{Being unemployed}

The most common key indicator with regard to the integration of young people into the labour market is the level of unemployment among school-leavers. As can be seen from Figure 4.2, the unemployment rates differ a great deal within the European Union. In Italy and Spain, around 40 percent of all school-leavers is unemployed. Also in Greece and Finland, a large proportion of young people entering the labour market is unemployed (in both countries 31 percent). In Luxembourg, Austria, Germany and Denmark, on the other hand, less than 10 percent of all school-leavers is without a job. All other countries take more or less a position in the middle, and the average unemployment rate within the European Union is 19 percent.

If a distinction is made between recent and less recent school-leavers (as is done in Table 4.4), we find that recent school-leavers are unemployed more frequently than less recent school-leavers. Of all youngsters within the European Union who left school less than one year ago, 30 percent is unemployed, whereas 17 percent of all less recent school-leavers has no job. The corresponding odds ratio is 2.09 $((30 / 70) /(17 / 83))$. Differences in the probability of being unemployed between recent and less recent school-leavers are most striking in the Netherlands, Finland and Portugal, where the odds of being unemployed versus employed for recent schoolleavers is at least four times higher than the corresponding odds for less recent school-leavers. In other countries, such as France, Denmark and Ireland, differences in the unemployment rates between recent and less recent school-leavers are only moderate. In Germany, there is no difference at all. The unemployment rate for both recent and less recent school-leavers is seven percent in this country. 
Figure 4.2

Share of school-leavers being unemployed, by country

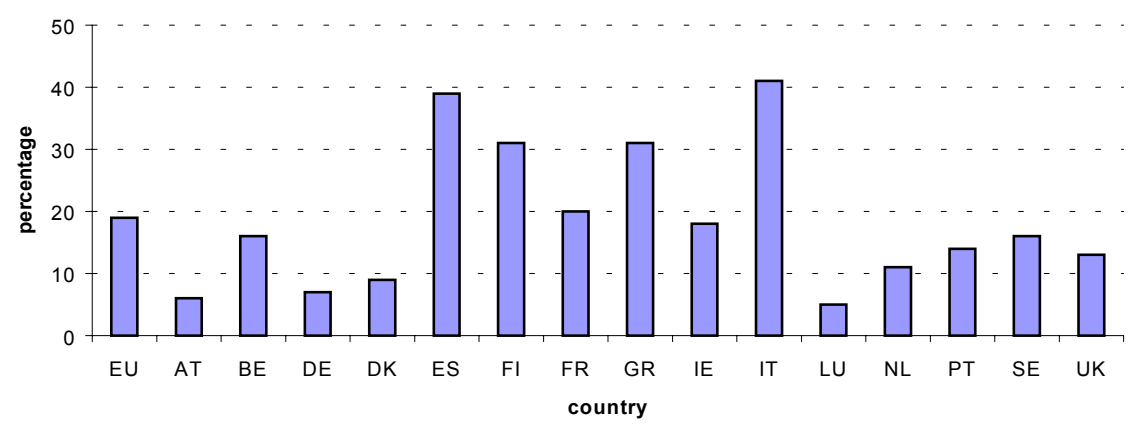

Source: pooled ECLFS-data 1992-1997

Table 4.4

Differences in shares of being unemployed, by type of school-leaver and country

\begin{tabular}{lccc}
\hline Country & $\begin{array}{c}\text { recent } \\
\text { school-leavers } \\
\%\end{array}$ & $\begin{array}{c}\text { less recent } \\
\text { school-leavers } \\
\%\end{array}$ & odds ratio \\
\hline European Union & 30 & 17 & 2.09 \\
Austria & 13 & 5 & 2.84 \\
Belgium & 30 & 14 & 2.63 \\
Germany & 7 & 7 & 1.00 \\
Denmark & 12 & 8 & 1.57 \\
Spain & 58 & 36 & 2.46 \\
Finland & 52 & 20 & 4.33 \\
France & 30 & 18 & 1.95 \\
Greece & 57 & 28 & 3.41 \\
Ireland & 22 & 17 & 1.38 \\
Italy & 67 & 35 & 3.77 \\
Luxembourg & 11 & 5 & 2.35 \\
Netherlands & 30 & 8 & 4.93 \\
Portugal & 35 & 11 & 4.36 \\
Sweden & 34 & 11 & 2.92 \\
United Kingdom & 20 & & \\
& & 11 & \\
\hline
\end{tabular}

Source: pooled ECLFS-data 1992-1997

In Table 4.5, the unemployment rates are broken down by educational level. Not surprisingly, there is a negative association between unemployment risk and level of education. The higher the level of education a school-leaver has attained, the smaller the likelihood that he/she is unemployed. Within the whole European Union, 26 percent of all lower educated school-leavers are unemployed. This figure goes down to 18 percent for those with a certificate at the intermediate level and to 14 for those with a degree in higher education. The negative association between unemployment risk and educational level is found in all countries, although there is a great deal of 
cross-country variation. The association is strongest in Finland, Ireland, Sweden and Belgium. In these countries, the protective effect of education against unemployment is clearest. In Denmark, Germany, Italy, Spain and Portugal, on the other hand, unemployment rates differ only to a small extent between levels of education. Note that this does not imply that these five countries are similar with respect to their unemployment levels. Although the relative difference in unemployment risk between lower and higher educated are the same in these countries, the absolute levels of unemployment are much higher in the South European countries than in Germany and Denmark.

Table 4.5

Differences in shares of being unemployed, by educational level and country

\begin{tabular}{|c|c|c|c|c|}
\hline Country & $\begin{array}{c}\text { ISCED0-2 } \\
\%\end{array}$ & $\begin{array}{c}\text { ISCED3 } \\
\%\end{array}$ & $\begin{array}{l}\text { ISCED5-7 } \\
\%\end{array}$ & odds ratio ${ }^{a}$ \\
\hline European Union & 26 & 18 & 14 & 2.16 \\
\hline Austria & 9 & 5 & 5 & 1.88 \\
\hline Belgium & 30 & 17 & 8 & 4.93 \\
\hline Germany & 8 & 8 & 5 & 1.65 \\
\hline Denmark & 9 & 10 & 7 & 1.31 \\
\hline Spain & 44 & 42 & 33 & 1.60 \\
\hline Finland & 56 & 28 & 13 & 8.52 \\
\hline France & 33 & 20 & 12 & 3.61 \\
\hline Greece & 25 & 36 & 26 & 0.95 \\
\hline Ireland & 35 & 16 & 9 & 5.44 \\
\hline Italy & 42 & 40 & 35 & 1.34 \\
\hline Luxembourg & 9 & 4 & 3 & 3.20 \\
\hline Netherlands & 18 & 9 & 8 & 2.52 \\
\hline Portugal & 14 & 18 & 10 & 1.47 \\
\hline Sweden & 24 & 19 & 6 & 4.95 \\
\hline United Kingdom & 19 & 13 & 7 & 3.12 \\
\hline
\end{tabular}

Source: pooled ECLFS-data 1992-1997

a: ISCED0-2 versus ISCED5-7

Unemployment rates differ between men and women as well (see Table 4.6). In most countries, female school-leavers are more often unemployed than their male counterparts. However, the differences are not very large. For the European Union as a whole, 21 percent of all female school-leavers are unemployed, whereas this share is 18 percent for men. The largest difference is found in Greece. In this country, an odds ratio of 2.05 is found. This implies that the odds of being unemployed for women is more than two times larger than the corresponding odds for men. In Ireland, the Netherlands, Sweden and the United Kingdom, men are more often unemployed at labour market entry than women. 
Table 4.6

Differences in shares of being unemployed, by gender and country

\begin{tabular}{lccc}
\hline Country & $\begin{array}{c}\text { women } \\
\%\end{array}$ & $\begin{array}{c}\text { men } \\
\%\end{array}$ & odds ratio \\
& & & \\
\hline European Union & 21 & 18 & 1.21 \\
Austria & 6 & 6 & 1.00 \\
Belgium & 17 & 15 & 1.16 \\
Germany & 7 & 7 & 1.00 \\
Denmark & 10 & 8 & 1.28 \\
Spain & 44 & 31 & 1.46 \\
Finland & 31 & 18 & 1.00 \\
France & 22 & 23 & 1.28 \\
Greece & 38 & 19 & 2.05 \\
Ireland & 16 & 36 & 0.81 \\
Italy & 45 & 5 & 1.45 \\
Luxembourg & 6 & 11 & 1.21 \\
Netherlands & 10 & 13 & 0.90 \\
Portugal & 16 & 17 & 1.27 \\
Sweden & 15 & 16 & 0.86 \\
United Kingdom & 11 & & 0.65 \\
& & & \\
\hline
\end{tabular}

Source: pooled ECLFS-data 1992-1997

\subsection{Having a temporary job}

Another important aspect of the integration process is job security. Having a temporary job increases the probability to fall back into unemployment again after expiration of the temporary contract, and reduces therefore the integration into the labour market. In Figure 4.3, the proportions of school-leavers with a temporary job across the countries of the European Union are displayed. Spain certainly has the top-rank position with regard to the share of school-leavers who are in temporary jobs. In this country, almost three quarters of all working young people who left school less than five years ago, do not have a permanent contract. In Finland, nearly half of the working school-leavers are in a temporary labour market position. These findings imply that in both countries the integration process of young people is not only hindered by a large number of individuals who cannot find a job (as shown in the Figures 4.1 and 4.2), but even the greater part of the youngsters who are employed, have a precarious labour market position in the sense that their contract is often temporary. Sweden, France and Portugal have a relatively large proportion of schoolleavers with a temporary contract as well. All other countries show percentages that are below the European Union average. Only in Luxembourg (six percent) and Austria (nine percent), less than one tenth of the employed school-leavers have a temporary work contract. 
Figure 4.3

Share of school-leavers having a temporary job, by country

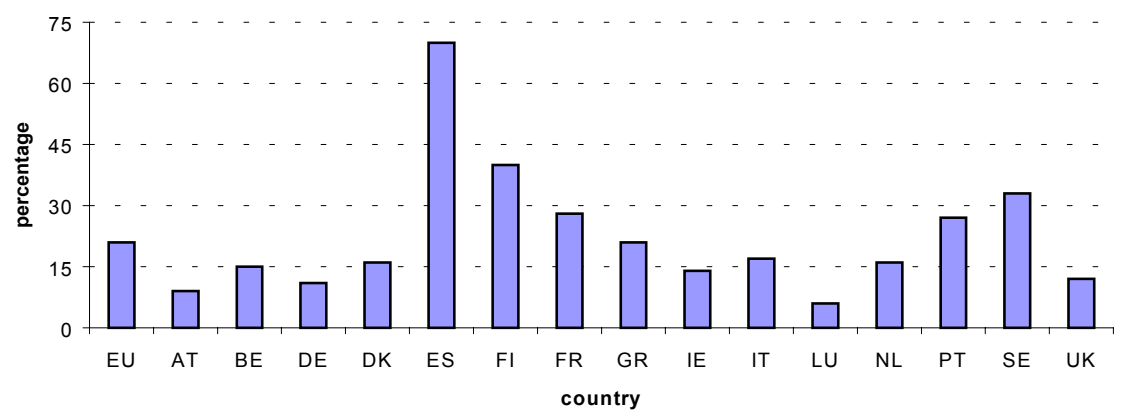

Source: pooled ECLFS-data 1992-1997

If we break down the share of youngsters holding a temporary job by type of schoolleaver, we find that, as expected, less recent school-leavers perform better than recent school-leavers (see Table 4.7). This table shows indeed that recent schoolleavers more often have a temporary job than less recent school-leavers. Of all recent school-leavers in the European Union, 43 percent has a temporary job, whereas of all less recent school-leavers, only 19 percent has a temporary job. Evidently, the additional few years of work experience that less recent school-leavers (may) have gained, decrease their likelihood of having a temporary job. The differences between less recent and recent school-leavers as regards to the permanency of the job, are greatest in Luxembourg, the Netherlands, Germany, France and Sweden. This indicates that in these countries youngsters have a relatively large probability to change their temporary job for a permanent one during the transition period. In Spain, although the probability of being in a temporary job is substantially lower for less recent school-leavers than for recent ones (the odds ratio is 3.01), the absolute share of less recent school-leavers who have a temporary job is much higher than in other countries. Nearly 70 percent of all Spanish youngsters who left school 1-5 years ago still has a temporary contract. In the European Union as a whole, this percentage is only 19 percent.

Table 4.8 differentiates the share of youngsters having a temporary job by level of education. In the European Union as a whole, low educated school-leavers run a somewhat greater risk of being in a temporary labour market position than high educated ones. One third of the low educated employed youngsters in the Member States has a temporary job, whereas high educated employed youngsters less regularly hold a temporary job (22 percent). Surprisingly enough, intermediate educated school-leavers are even less often working on a temporary basis than high educated (17 percent). If we look at the individual countries, then we see a mixed situation between countries. There are only two countries that behave according to the European Union pattern: Germany and the Netherlands. In Denmark, Spain, Finland, France, Greece, Portugal and Sweden, there is a negative relationship between the probability of youngsters having a temporary job and the level of 26 
education attained. In all other countries, school-leavers with a degree in higher education are more often working on the basis of a temporary contract than schoolleavers with only basic qualifications.

Table 4.7

Differences in shares of having a temporary job, by type of school-leaver and country

\begin{tabular}{lccc}
\hline Country & $\begin{array}{c}\text { recent } \\
\text { school-leavers } \\
\%\end{array}$ & $\begin{array}{c}\text { less recent } \\
\text { school-leavers } \\
\%\end{array}$ & odds ratio \\
\hline European Union & 43 & 19 & 3.22 \\
Austria & 25 & 8 & 3.83 \\
Belgium & 33 & 13 & 3.30 \\
Germany & 36 & 10 & 5.06 \\
Denmark & 36 & 13 & 3.76 \\
Spain & 87 & 69 & 3.01 \\
Finland & 67 & 34 & 3.82 \\
France & 59 & 25 & 4.32 \\
Greece & 36 & 20 & 2.25 \\
Ireland & 31 & 11 & 3.64 \\
Italy & 37 & 3 & 8.08 \\
Luxembourg & 20 & 15 & 5.90 \\
Netherlands & 51 & 24 & 3.72 \\
Portugal & 54 & 28 & 4.20 \\
Sweden & 62 & 9 & 3.55 \\
United Kingdom & 26 & & \\
& & & \\
\hline
\end{tabular}

Source: pooled ECLFS-data 1992-1997

Table 4.8

Differences in shares of having a temporary job, by educational level and country

\begin{tabular}{lcccc}
\hline Country & $\begin{array}{c}\text { ISCED0-2 } \\
\%\end{array}$ & $\begin{array}{c}\text { ISCED3 } \\
\%\end{array}$ & $\begin{array}{c}\text { ISCED5-7 } \\
\%\end{array}$ & odds ratio $^{\text {a }}$ \\
& & & & \\
\hline European Union & 32 & 17 & 22 & 1.67 \\
Austria & 14 & 7 & 20 & 0.65 \\
Belgium & 14 & 12 & 18 & 0.74 \\
Germany & 22 & 10 & 13 & 1.89 \\
Denmark & 27 & 15 & 13 & 2.48 \\
Spain & 82 & 70 & 59 & 3.17 \\
Finland & 62 & 40 & 36 & 2.90 \\
France & 42 & 29 & 22 & 2.57 \\
Greece & 28 & 20 & 19 & 1.66 \\
Ireland & 13 & 13 & 15 & 0.85 \\
Italy & 17 & 17 & 21 & 0.77 \\
Luxembourg & 5 & 6 & 7 & 0.70 \\
Netherlands & 25 & 13 & 18 & 1.52 \\
Portugal & 24 & 33 & 33 & 0.64 \\
Sweden & 44 & 31 & 13 & 1.83 \\
United Kingdom & 12 & 10 & & 0.91 \\
& & & &
\end{tabular}

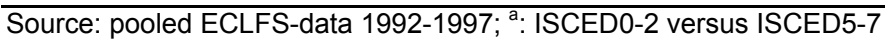


On the European level, there are no gender differences with regard to the proportion of school-leavers working in a temporary job (see Table 4.9). Both men and women have the same probability of having a temporary contract: 21 percent. There is, of course, some cross-country variation, but the differences are moderate. In Germany, Spain, Greece and the Netherlands, women are somewhat less often working on a temporary basis. In Luxembourg and the United Kingdom, male school-leavers are as often working in a temporary job as their female counterparts. In all other countries, women are in an advantageous position.

One might argue, however, whether the permanency of a job is a valid key indicator to measure the integration of young people into the labour market. If the temporary job is voluntary, i.e. it is not the situation on the labour market which urges youngsters to accept a temporary job, but it is their wish to have a temporary job, then it is no valid key indicator. Only if having a temporary job is involuntary, youngsters are restricted in their labour market behaviour and only in that case the permanency of the job is important for our analysis.

Table 4.9

Differences in shares of having a temporary job, by gender and country

\begin{tabular}{|c|c|c|c|}
\hline Country & $\begin{array}{c}\text { women } \\
\%\end{array}$ & $\begin{array}{c}\text { men } \\
\%\end{array}$ & odds ratio \\
\hline European Union & 21 & 21 & 1.00 \\
\hline Austria & 10 & 8 & 1.28 \\
\hline Belgium & 17 & 12 & 1.50 \\
\hline Germany & 9 & 13 & 0.66 \\
\hline Denmark & 20 & 12 & 1.83 \\
\hline Spain & 68 & 71 & 0.87 \\
\hline Finland & 46 & 33 & 1.73 \\
\hline France & 29 & 27 & 1.10 \\
\hline Greece & 20 & 22 & 0.89 \\
\hline Ireland & 16 & 12 & 1.40 \\
\hline Italy & 18 & 17 & 1.07 \\
\hline Luxembourg & 6 & 6 & 1.00 \\
\hline Netherlands & 15 & 16 & 0.93 \\
\hline Portugal & 29 & 25 & 1.23 \\
\hline Sweden & 39 & 26 & 1.82 \\
\hline United Kingdom & 12 & 12 & 1.00 \\
\hline
\end{tabular}

Source: pooled ECLFS-data 1992-1997

In Table 4.10, we show the reasons for not having a permanent job. The main reason is that school-leavers cannot find a permanent job. This is the case for 44 percent of all employed youngsters who have a temporary position. For less recent schoolleavers, this percentage is even somewhat higher (46 percent). Voluntarily accepting a temporary job, occurs only in isolated instances (five percent overall) and is no serious reason why youngsters accept a temporary job. Therefore, we conclude that the permanency of the job is an adequate key indicator to determine the integration of young people into the labour market. 
Table 4.10

Reasons for having a temporary job, by type of school-leaver

\begin{tabular}{lccc}
\hline Reason & $\begin{array}{c}\text { total } \\
\text { school-leavers } \\
\%\end{array}$ & $\begin{array}{c}\text { recent } \\
\text { school-leavers } \\
\%\end{array}$ & $\begin{array}{c}\text { less recent } \\
\end{array}$ \\
& & & 16 \\
Temporary job including training & 11 & 33 & 10 \\
Couldn't find permanent job & 44 & 7 & 46 \\
Temporary job because of probation & 5 & 9 & 3 \\
Didn't want permanent job & 5 & 36 & 37 \\
No reason & 36 & & 3
\end{tabular}

Source: pooled ECLFS-data 1992-1997

\subsection{Having a part-time job}

Another feature of job security is the number of hours per week that school-leavers work in their job. In Figure 4.4, we present the share of employed youngsters who have a part-time job. It appears that throughout the European Union, the vast majority of employed school-leavers has found a full-time job. On average 11 percent of all employed youngsters have a part-time job. In some countries, however, the share of youngsters who have a part-time job is substantially higher. These countries are Sweden (33 percent) and the Netherlands (23 percent). In Luxembourg and Portugal, on the other hand, only four percent of all school-leavers works in a part-time job.

Figure 4.4

Share of school-leavers having a part-time job, by country

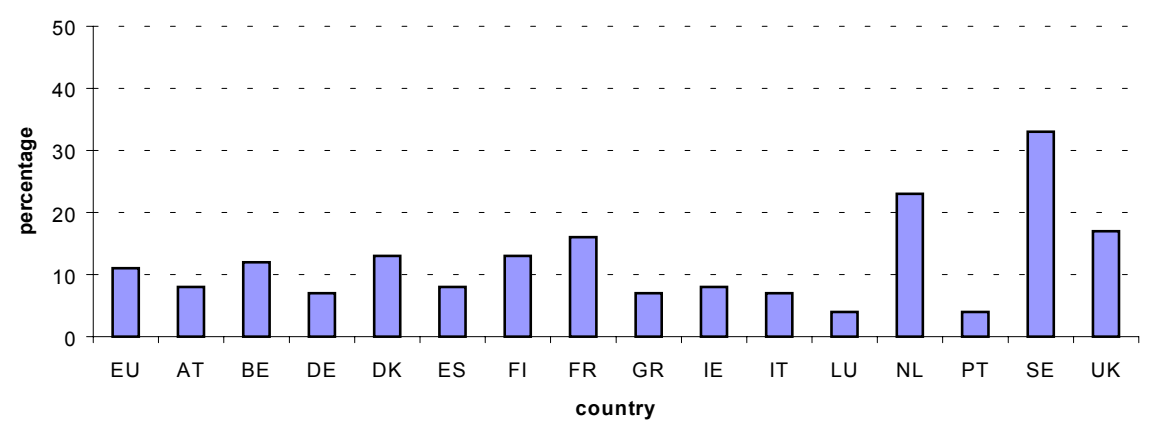

Source: pooled ECLFS-data 1992-1997

Recent school-leavers more often have a part-time job than less recent schoolleavers. This can be concluded from Table 4.11. In the European Union as a whole, 22 percent of all recent school-leavers has a part-time job, whereas only ten percent of all less recent school-leavers works part-time. The corresponding odds ratio is 2.54. Between countries there is considerable variation with regard to differences between recent and less recent school-leavers. In the United Kingdom and Sweden, 
the differences between recent and less recent school-leavers are largest. In Belgium and the Netherlands, the differences are smallest. The contrasting findings for Sweden and the Netherlands are very interesting in this respect. These two countries have the highest rates of part-time employment within in the European union, but for different reasons. In Sweden, the high level of part-time employment appears to be a matter of integration into the labour market, whereas in the Netherlands it seems to be a more general characteristic of the labour force.

Table 4.11

Differences in shares of having a part-time job, by type of school-leaver and country

\begin{tabular}{lccc}
\hline Country & $\begin{array}{c}\text { recent } \\
\text { school-leavers } \\
\%\end{array}$ & $\begin{array}{c}\text { less recent } \\
\text { school-leavers } \\
\%\end{array}$ & odds ratio \\
\hline European Union & 22 & 10 & 2.54 \\
Austria & 15 & 8 & 2.03 \\
Belgium & 14 & 12 & 1.19 \\
Germany & 11 & 6 & 1.94 \\
Denmark & 24 & 11 & 2.56 \\
Spain & 12 & 7 & 1.81 \\
Finland & 24 & 11 & 2.56 \\
France & 25 & 7 & 1.89 \\
Greece & 10 & 6 & 1.48 \\
Ireland & 15 & 7 & 1.48 \\
Italy & 10 & 4 & 2.09 \\
Luxembourg & 8 & 23 & 1.30 \\
Netherlands & 28 & 4 & 1.53 \\
Portugal & 6 & 30 & 3.09 \\
Sweden & 57 & 14 & 3.46 \\
United Kingdom & 36 & & \\
& & & \\
\hline
\end{tabular}

Source: pooled ECLFS-data 1992-1997

Table 4.12 presents the relationship between level of education and part-time employment. In the European Union as a whole, lower educated school-leavers are more likely to be in a part-time job than higher educated. Of all school-leavers with a certificate at the level of ISCED0-2, 15 percent has a part-time job. At the ISCED3 level, the percentage is 11 and at the ISCED5-7 level it is nine percent. Between countries, however, we see a much more differentiated picture. In the Scandinavian countries Sweden and Finland, we find the largest variation between levels of education. The ratio between the odds of being in a part-time versus full-time job for the lowest educated and the corresponding odds for the highest educated in these countries, are 9.67 and 7.04, respectively. In other countries, only a very weak association (Spain, the Netherlands) or even no association (Austria, Greece) is found. Again, it seems that the high rates of part-time employment in Sweden and the Netherlands stem from different reasons. In Sweden, part-time employment is mainly concentrated among less integrated young people (in this case: lower educated), whereas in the Netherlands this form of atypical employment is a general feature of the Dutch labour market. Finally, in Italy, Luxembourg and Portugal, it is found that higher educated school-leavers more often have a part-time position in the 
labour market than lower educated ones. These are all countries where part-time employment hardly exists anyhow.

Table 4.12

Differences in shares of having a part-time job, by educational level and country

\begin{tabular}{|c|c|c|c|c|}
\hline Country & $\begin{array}{l}\text { ISCED0-2 } \\
\%\end{array}$ & $\begin{array}{c}\text { ISCED3 } \\
\%\end{array}$ & $\begin{array}{l}\text { ISCED5-7 } \\
\%\end{array}$ & odds ratio ${ }^{a}$ \\
\hline European Union & 15 & 11 & 9 & 1.78 \\
\hline Austria & 13 & 7 & 13 & 1.00 \\
\hline Belgium & 15 & 13 & 10 & 1.59 \\
\hline Germany & 12 & 5 & 8 & 1.57 \\
\hline Denmark & 25 & 11 & 11 & 2.70 \\
\hline Spain & 8 & 8 & 7 & 1.16 \\
\hline Finland & 31 & 16 & 6 & 7.04 \\
\hline France & 25 & 18 & 9 & 3.37 \\
\hline Greece & 8 & 6 & 8 & 1.00 \\
\hline Ireland & 10 & 8 & 6 & 1.74 \\
\hline Italy & 5 & 7 & 10 & 0.47 \\
\hline Luxembourg & 4 & 2 & 6 & 0.65 \\
\hline Netherlands & 27 & 23 & 23 & 1.24 \\
\hline Portugal & 4 & 4 & 6 & 0.65 \\
\hline Sweden & 72 & 29 & 21 & 9.67 \\
\hline United Kingdom & 31 & 18 & 9 & 4.54 \\
\hline
\end{tabular}

Source: pooled ECLFS-data 1992-1997

a: ISCED0-2 versus ISCED5-7

Gender differences with regard to part-time employment are quite clear (see Table 4.13). In all Member States, female school-leavers are more often found in part-time jobs than their male counterparts. On average, 17 percent of all young women within the European Union have a part-time job as against six percent for young men. Of course, there is considerable cross-country variation. In Germany, Belgium, Austria, the Netherlands and France, the differences between women and men with regard to part-time employment are largest, whereas in Greece and Ireland, the differences are smallest.

Again, just like having a temporary job, having a part-time job is only interesting for the analysis of the integration process of young people into the labour market if their part-time status is involuntary. Table 4.14 displays the reasons why youngsters have a part-time job. In this table, we see that the majority of school-leavers starts in a part-time job involuntarily, due to the fact that they could not find a full-time position (43 percent), or that they combine their part-time work with schooling (16 percent). The last argument especially applies to recent school-leavers. This confirms the idea that the transition from school to work is a process and not just simply a shift from full-time education to stable full-time employment.. The third reason why schoolleavers work part time is that they do not want a full-time job (29 percent). This percentage is mainly dominated by less recent and female school-leavers. Especially for the latter group, part-time employment is a voluntary choice (for instance to make time for raising children) rather than lacking opportunities to integrate into the labour 
market. Other reasons for part-time employment are mentioned only rarely. This brings us to the conclusion that, in many cases, part-time employment among school-leavers is involuntary and, therefore, seems to be an appropriate measure to investigate the integration of young people into the labour market.

Table 4.13

Differences in shares of having a part-time job, by gender and country

\begin{tabular}{lccc}
\hline Country & $\begin{array}{c}\text { women } \\
\%\end{array}$ & $\begin{array}{c}\text { men } \\
\%\end{array}$ & odds ratio \\
& & & \\
\hline European Union & 17 & 6 & 3.21 \\
Austria & 13 & 3 & 4.83 \\
Belgium & 20 & 4 & 6.00 \\
Germany & 12 & 2 & 6.68 \\
Denmark & 20 & 6 & 3.92 \\
Spain & 12 & 5 & 2.59 \\
Finland & 18 & 9 & 2.22 \\
France & 25 & 6 & 1.53 \\
Greece & 9 & 6 & 1.55 \\
Ireland & 9 & 2 & 2.67 \\
Italy & 10 & 11 & 3.69 \\
Luxembourg & 7 & 3 & 4.36 \\
Netherlands & 35 & 21 & 2.06 \\
Portugal & 6 & 13 & 3.08 \\
Sweden & 45 & & 2.00 \\
United Kingdom & 23 & & \\
& & 6 & \\
\hline
\end{tabular}

Source: pooled ECLFS-data 1992-1997

Table 4.14

Reasons for having a part-time job, by type of school-leaver and gender

\begin{tabular}{lrrrrr}
\hline Reason & total & $\begin{array}{r}\text { recent } \\
\text { school- } \\
\text { leaver } \\
\%\end{array}$ & $\begin{array}{c}\text { less recent } \\
\text { school- } \\
\text { leaver } \\
\%\end{array}$ & male & female \\
\hline Combining schooling and part-time work & 16 & 36 & 10 & 26 & $\%$ \\
Couldn't find a full-time job & 43 & 42 & 44 & 46 & 12 \\
Didn't want a full-time job & 29 & 14 & 33 & 16 & 34 \\
Unable to work full-time due to illness & 1 & 0 & 1 & 1 & 1 \\
Other reason for having part-time work & 10 & 7 & 11 & 9 & 10 \\
No reason for having part-time work & 2 & 2 & 2 & 2 & 1 \\
\hline Source: pooled ECLFS-data 1992-1997 & & & & &
\end{tabular}




\section{The role of institutional settings}

Now that the gross cross-country differences with regard to our four key indicators have been described, we try to explain this variation between countries by taking into account the impact of institutional arrangements, both with regard to the employment system and the education/training system. Moreover, we statistically control for the effect of the labour market situation. This gives us insight in the true performance of youth labour markets. However, before presenting the results of multilevel analysis, applied for this purpose, we need to describe (the operationalisation of) the national institutional contexts both with regard to the employment system and the education/training system, and the general labour market situation in the various countries.

\subsection{National institutional contexts}

To measure the level of centralisation and co-ordination of the wage bargaining structure in a country, we created three distinct categories. Table 5.1 shows that Austria and Germany are defined as countries with a centralised/co-ordinated wage bargaining system. Ireland and the United Kingdom are classified as decentralised/ unco-ordinated. All other countries within the European Union represent systems in which wage bargaining takes place at the intermediate level.

The power of trade unions is operationalised as the percentage of workers who are members of a trade union. Trade union membership within the European Union is most common in the Scandinavian countries. In France and Spain, on the other hand, the union density is rather low.

Employment protection, measured by the overall strictness of employment protection legislation, is by far the strictest in the South European countries. In Ireland and the United Kingdom, however, the existing labour force has relatively little protection against dismissals and other forms of job insecurity.

Active labour market policies for youngsters are operationalised as the percentage of Gross Domestic Product (GDP) spent on youth measures. From Table 5.1, it can be observed that there are considerable differences between European countries with regard to the amount of money spent on youth measures. Italy, Portugal, France and Ireland spend relatively spoken the largest amounts of money on youth measures, whereas in countries such as Austria, Belgium, Sweden, Germany and the Netherlands, the percentage of GDP spent on active labour market policies for youngsters is relatively small.

In Table 5.2, the countries are classified by institutional characteristics with regard to their education/training system. The vocational specificity of the education system is operationalised by two indicators. First of all, it is measured by the percentage of upper secondary students enrolled in vocational education. Especially in the countries around Germany and the Scandinavian countries, secondary education is vocational-oriented, whereas in South European and the United Kingdom and 
Ireland, the general track is predominant within secondary education. In addition, we make a distinction between countries that have institutionalised vocational training by means of a separate system ('dual system'), and countries in which vocational training is solely school-based. Countries that have a significant dual system are Austria, Germany, Denmark, Luxembourg and the Netherlands.

Table 5.1

National institutional contexts with regard to the employment system

\begin{tabular}{|c|c|c|c|c|}
\hline Country & $\begin{array}{l}\text { wage bargaining } \\
\text { structure }^{a}\end{array}$ & $\begin{array}{l}\text { union } \\
\text { density }(\%)^{b}\end{array}$ & $\begin{array}{l}\text { employment } \\
\text { protection }^{c}\end{array}$ & $\begin{array}{l}\text { youth measures } \\
(\% \text { of GDP })^{d}\end{array}$ \\
\hline Austria & 3 & 42 & 2.2 & 0.01 \\
\hline Belgium & 2 & 54 & 2.6 & 0.04 \\
\hline Germany & 3 & 29 & 2.9 & 0.07 \\
\hline Denmark & 2 & 76 & 1.7 & 0.20 \\
\hline Spain & 2 & 19 & 3.4 & 0.08 \\
\hline Finland & 2 & 81 & 2.1 & 0.20 \\
\hline France & 2 & 9 & 2.9 & 0.28 \\
\hline Greece & 2 & 24 & 3.6 & 0.03 \\
\hline Ireland & 1 & 49 & 0.9 & 0.28 \\
\hline Italy & 2 & 39 & 3.7 & 0.58 \\
\hline Luxembourg & 2 & 43 & 2.5 & 0.10 \\
\hline Netherlands & 2 & 26 & 2.4 & 0.09 \\
\hline Portugal & 2 & 32 & 3.9 & 0.35 \\
\hline Sweden & 2 & 91 & 2.4 & 0.02 \\
\hline United Kingdom & 1 & 34 & 0.5 & 0.13 \\
\hline
\end{tabular}

${ }^{a}$ Wage bargaining structure is a combined indicator that measures the degree of centralisation and co-ordination of the wage bargaining system in a country. The values are based on data for 1994, as reported in OECD Employment Outlook of 1997 (OECD, 1997: Table 3.3). A '3' indicates a centralised/co-ordinated wage bargaining structure, a ' 2 ' is assigned to countries with an intermediate wage bargaining structure and a '1' refers to countries where wage bargaining is decentralised/unco-ordinated. The value for Ireland is based on Nickell and Layard (1997). Greece and Luxembourg are, for lack of data, assigned to the European Union average.

b Trade union density is based on the rates of 1994 as published in OECD Employment Outlook of 1997 (OECD 1997: Table 3.3). The figures for Greece and Ireland stem from Ebbinghaus and Visser (1999) and are the rates of 1995. The union density rate for Luxembourg is the unweighted average of the other countries.

c Employment protection is measured by the overall strictness of employment protection legislation (EPL) in a country, as published in OECD Employment Outlook of 1999 (OECD, 1999: Table 2.5). This summary indicator refers to protection with regard to both regular and temporary employment. The figures used here are the averages of the scores for the late 1980s and late 1990s. The figure for Luxembourg is computed as the unweighted average of all other countries, since there is no data available for this country.

d Youth measures are based on the percentage of Gross Domestic Product (GDP) spent on these measures in a country averaged over the period 1992-1997. The original yearly percentages were reported in OECD Employment Outlook of 1996 (OECD, 1996: Table T), 1997 (OECD, 1997: Table K), 1998 (OECD, 1998: Table J) and 1999 (OECD, 1999: Table H).

Related to the vocational specificity is the stratification of the education system. In this study, we define the secondary education systems of Austria, Germany, Luxembourg and the Netherlands as highly stratified, in the sense that pupils are differentiated into tracks very early in their educational careers (at the end of primary 
education already). The South European and Scandinavian countries, on the other hand, represent countries with a low degree of stratification of secondary education.

The selectivity of the education system is operationalised as the percentage of the population that has attained tertiary education. It is assumed that in countries in which the attainment of tertiary education is high, the education system is more expanded and, therefore, less selective. From Table 5.2, we see that the highest percentages can be found in Belgium, Sweden, Ireland, Denmark and Spain. Austria, Italy and Portugal, show the lowest proportions of persons with higher education.

Table 5.2

National institutional contexts with regard to the education/training system

\begin{tabular}{|c|c|c|c|c|}
\hline Country & $\begin{array}{l}\text { vocational } \\
\text { specificity } \\
\text { sec. educ. } \\
\text { (\%) }\end{array}$ & $\begin{array}{l}\text { dual } \\
\text { system }^{b}\end{array}$ & $\begin{array}{l}\text { stratification } \\
\text { sec. educ. }\end{array}$ & $\begin{array}{l}\text { tertiary } \\
\text { education } \\
\text { qual. }^{d} \\
\quad(\%)\end{array}$ \\
\hline
\end{tabular}

\begin{tabular}{|c|c|c|c|c|}
\hline Austria & 76 & 1 & 2 & 8 \\
\hline Belgium & 59 & 0 & 1 & 29 \\
\hline Germany & 80 & 1 & 2 & 21 \\
\hline Denmark & 56 & 1 & 0 & 25 \\
\hline Spain & 41 & 0 & 1 & 24 \\
\hline Finland & 54 & 0 & 0 & 22 \\
\hline France & 54 & 0 & 1 & 23 \\
\hline Greece & 21 & 0 & 1 & 18 \\
\hline Ireland & 0 & 0 & 0 & 27 \\
\hline Italy & 67 & 0 & 1 & 8 \\
\hline Luxembourg & 54 & 1 & 2 & 18 \\
\hline Netherlands & 70 & 1 & 2 & 23 \\
\hline Portugal & 14 & 0 & 0 & 12 \\
\hline Sweden & 76 & 0 & 0 & 26 \\
\hline United Kingdom & 58 & 0 & 0 & 23 \\
\hline
\end{tabular}

a Vocational specificity of secondary education is measured as the percentage of upper secondary students enrolled in public and private vocational education (including apprenticeships). The figures were reported in OECD Education at a Glance 1995 (OECD, 1995: Table P03(B)). The percentages for Greece, Ireland, Luxembourg, Portugal and Sweden are based on Figure 9 of Müller and Wolbers (1999).

b A ' 1 ' represents countries with an apprenticeship system in which learning and working are combined ('dual system'). All other countries are assigned to category '0', which indicates the absence of an elaborated dual system.

c Stratification of secondary education is based on Table 1.1.a of Müller and Shavit (1999). It is coded as follows: a ' 0 ' represents the prevalence of comprehensive schools which may or may not practise curricular and/or ability-based tracking. A '1' represents a prevalence of between-school tracking such that those on the academic track usually attend separate schools from those on the lower or vocational track. A '2' represents an extreme form of stratification with very early differentiation among a multitude of programmes. For Austria, Belgium, Denmark, Spain, Finland, Greece, Luxembourg and Portugal, all of which are countries that are missing in Müller and Shavit (1999), we took the information on the stratification of secondary education as reported in Hannan et al. (1999) and OECD (1995).

d Percentage of the population (25-59 years of age) that has attained any degree in tertiary education (ISCED5-7) is used as an indicator of the selectivity of the education system. The figures originate from Figure 2 of Müller and Wolbers (1999). 
Figure 5.1

Aggregate unemployment rates, by country and period

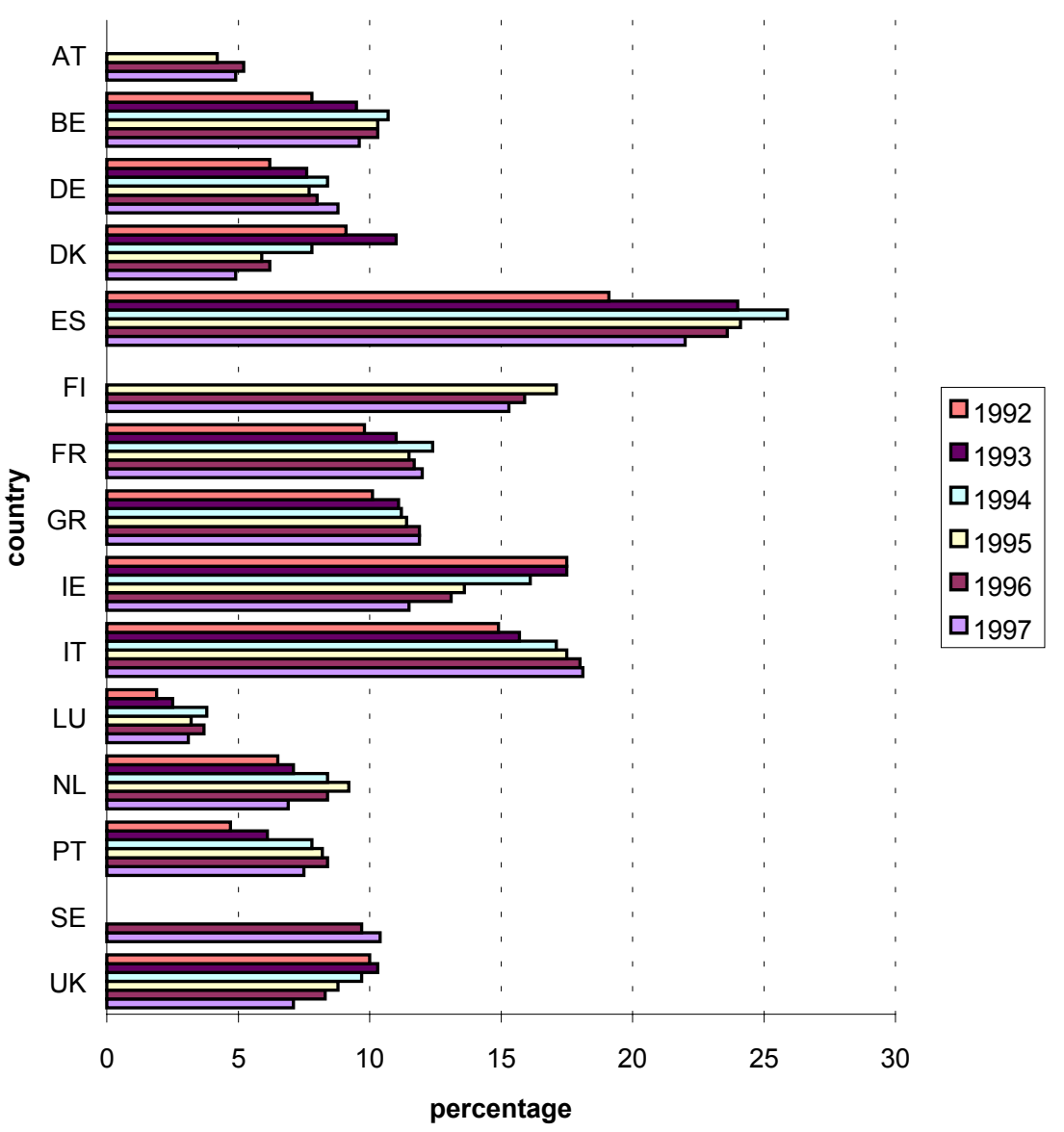

Source: pooled ECLFS-data 1992-1997

\subsection{General labour market situation}

To take differences in the general labour market situation between countries over time into account, we introduce aggregate unemployment rates into our analysis. The unemployment levels are based on the unemployed labour force aged between 15 and 59 years. The cross-country variation of trends over the period 1992-1997 is presented in Figure 5.1. From this figure, it can be observed that countries are indeed at different stages of the business cycle. In countries such as Germany, we find a rather low, but increasing level of unemployment. In countries such as Ireland, on the other hand, a clear decrease in the overall unemployment rate can be observed. Other countries show a fluctuating trend over time. In the Netherlands, for instance, we observe a rising percentage of unemployed people for the first years, followed by a decline in the later years. 


\subsection{Odds of being out of the labour force}

Table 5.3 presents the results of multilevel analysis related to the odds of being out of the labour force. Model 0 gives an estimation of the systematic variation between countries ('between-country variation') and the variation within countries between the different time periods ('within-country variation'). Because of the dichotomous nature of the dependent variable, the variation at the individual level cannot be estimated and, therefore, is fixed at the value 1 . The same applies for the other dependent variables in this chapter. Consequently, we are not able to estimate the extent to which this variation can be explained by the predictors in the different models. Nor can the variation between countries or between time periods be expressed as a proportion of the total variance. The different variance components are displayed at the bottom of the table. The variance component of Model 0 shows the 'gross' variation between countries in the odds of being out of the labour force. This gross variation is in principle the same as the differences in labour force participation shown earlier in Figure 4.1. The gross variation between countries amounts to 0.174 and is significant $(p<0.05)$, which means that there are significant differences between countries in the odds of school-leavers being out of the labour force. At the same time, however, the within-country variation is also significant and about the same magnitude as the between-country variation, namely 0.141 . This means that the differences in labour force participation within a country between the years is about as large as the differences between the countries.

Model 1 includes the individual characteristics: type of school-leaver, level of education and gender. All of these variables have a significant effect on the odds of being out of the labour force. For a recent school-leaver the odds of being out of the labour force is almost three times higher $\left(e^{1.070}=2.915\right)$ than the corresponding odds for a less recent school-leaver. There are large effects of the attained level of education. For persons who have left education at ISCED0-2 level, the odds is 3.445 $\left(e^{1.237}\right)$ times higher than for those who left at ISCED5-7 level, while for those who left at ISCED3 level, the odds increases with 81 percent $\left(e^{0.591}=1.806\right)$. Being a female also increases the odds of being out of the labour force, although the effect is far less important than the effect of the other two variables. Interesting is the fact that the introduction of these individual-level variables also influences the differences between the countries and especially the differences within the countries between the years. The remaining variance at the period level decreases from 0.141 in Model 0 to 0.046 in Model 1, indicating that about two thirds [(0.141-0.046)/0.141] of the original differences between the years are due to the individual characteristics. To a lesser extent, the same applies for the between-country variation. Here the remaining variance decreases from 0.174 to 0.135 , indicating that about one quarter of the original differences between countries can be attributed to differences between individuals. Further analysis (not shown here) reveals that the decrease in the variance component at the period level is mainly due to the type of school-leaver variable and, to a lesser extent, to the level of education. This can be interpreted as follows. Within a country, the participation rate of school-leavers varies from year to year. This variation is mainly due to different integration processes of especially recent school-leavers. One possible cause of this within-country variation may be the 
abolition of compulsory military service, or different reaction patterns of recent school-leavers and/or school-leavers from the lower educational levels to changes in the employment situation: when the prospects on the labour market are bad, recent school-leavers and school-leavers from the lower educational levels 'choose' temporarily not to participate in the labour force (the so-called 'discouraged-worker effect').

Model 2 seems to indicate that this discouraged-worker effect indeed takes place: the aggregate unemployment rate has a significant effect on the odds of being out of the labour force. Each percentage increase in the aggregate unemployment rate, increases the odds of school-leavers being out of the labour force with five percent $\left(e^{0.047}=1.048\right)$. The effects of the individual-level variables remain largely unchanged, indicating that these operate independently from the general employment situation. Differences in the aggregate unemployment rates do explain a significant portion of the between-country variation, where the residual variance decreases from 0.135 to 0.093 , indicating that almost half of the original variance between countries can be explained by differences in the composition of the population of school-leavers (type of school-leaver, level of education, gender) and by differences in the general employment situation.

In a sense, one can argue that the variables in Model 2 explain only one part of the differences in the integration process. One can consider the differences between countries in the integration of young people as the sum of two components. One relates to the above-mentioned factors: differences in the composition of the population of school-leavers and differences in general employment conditions. Both factors are more generic in nature and relate to the integration process in general. The other component relates to the institutional differences between countries. These can relate to characteristics of the employment system and/or the education system. Both institutional contexts can have an effect on the integration process of young people into the labour market. These national institutional factors are included in Models 3 to 5 .

Model 3 includes characteristics of the employment system. These characteristics indicate whether the system is 'open' for newcomers on the labour market or whether it intends to protect the existing labour force from these newcomers. None of the indicators included seem to have any effect at all on the odds of school-leavers being forced out of the labour force. Consequently, there is no change in the residual variance at the within-country or the between-country level. 


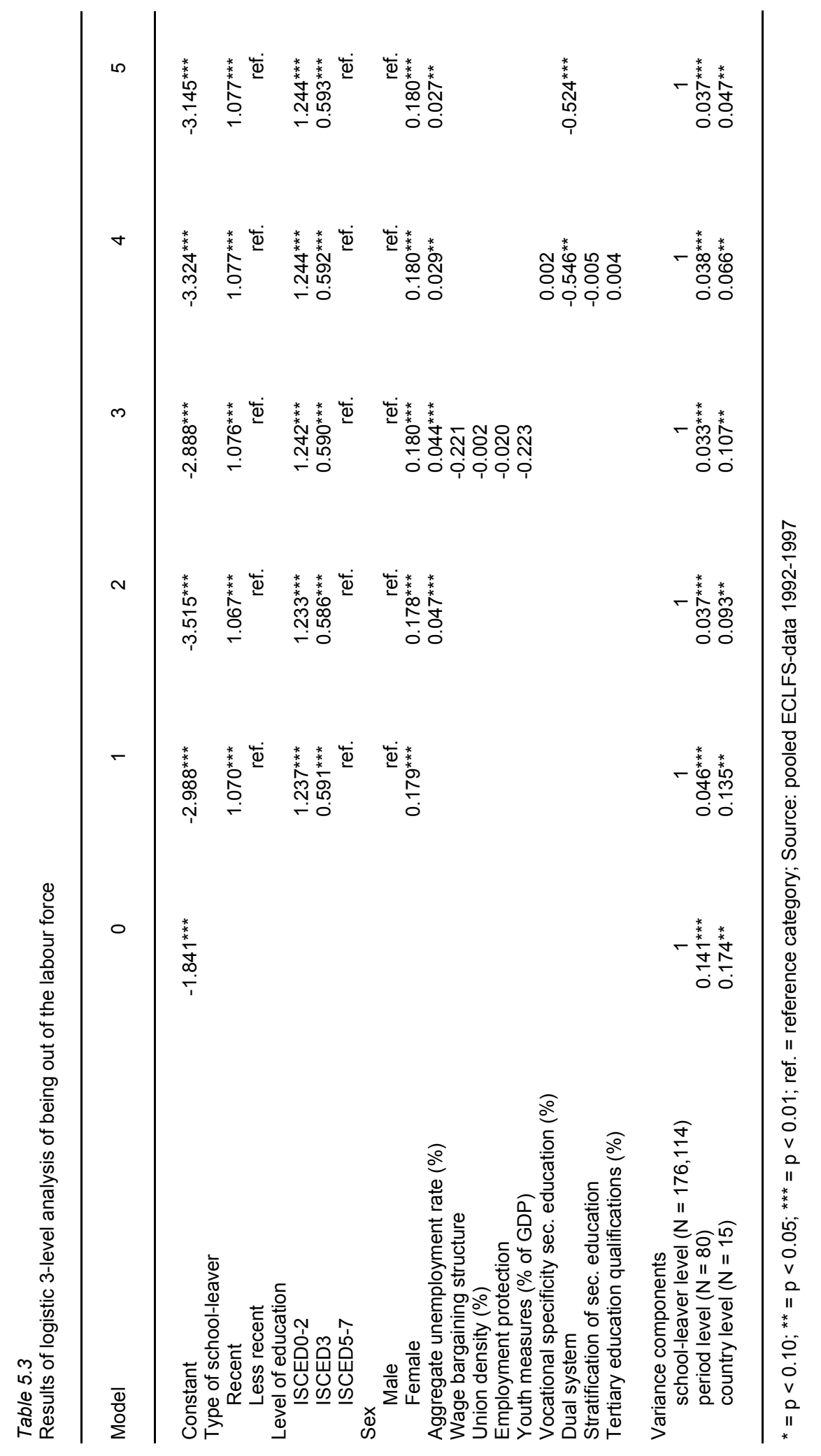


In Model 4, we include characteristics of the education and training system. Here we see that for countries that have a dual system, the odds of school-leavers being out of the labour force is $0.579\left(\mathrm{e}^{-0.524}\right)$ times smaller than the corresponding odds for countries that do not have a dual system. The introduction of this variable causes the residual variance to drop from 0.093 in Model 2 to 0.066 in Model 4. This finding clearly supports hypothesis 5 . The other characteristics of the education/training system have no significant effect. They even seem to deteriorate the model fit given the further decrease of the residual between-country variation in Model 5, in which only the significant variables are included. Note that the effect of the variable dual system is not per se related to the vocational specificity of the education system. As dual systems are by definition strongly vocation-oriented, it is important to distinguish between these two characteristics. The positive effect of having a dual system on the integration process of young people, stems from the strong allocation function of the dual system: the pathway it provides for young people to enter the labour market. The effect does not seem so much to be related to the more strongly vocational orientation of countries with a dual system, since the effect of the proportion of secondary education students enrolled in vocational programmes is not significant.

The conclusion is that there are significant differences between countries and within countries between the years, in the odds of being out of the labour force. The largest part of the differences between countries and between different periods within countries can be explained by the variables in our model. The most important are: the composition of the population of school-leavers with respect to type of schoolleaver, level of education and gender, differences in the general employment situation and the existence of a dual system. Together, these characteristics explain three quarters of the original differences within countries between the different time periods, as well as three quarters of the original differences between countries.

The effects of these variables become most clear if we look at the so-called 'posterior means' (see the Appendix for a detailed interpretation of posterior means). In principal, a posterior mean reflects the performance of a country as a deviation from the overall performance within the European Union, possibly after controlling for other variables. Figure 5.2 displays the posterior means for three different models. The posterior means of Model 0 are similar to the observed percentages of Figure 4.1. However, these percentages are now expressed as deviations from the overall percentage within the European Union, in a somewhat different scale (a log odds ratio scale). Nevertheless, the pattern of differences in performance between the countries follows exactly the description of the differences as presented earlier. We see high proportions in the United Kingdom, Finland and Ireland, and low proportions in Luxembourg and the Netherlands. The posterior means of the countries in the other two models show what happens if certain variables are controlled for. Take for example the case of Finland. Model 0 shows a very low performance (i.e. very high posterior mean) for Finland, indicating that this country has a very large proportion of school-leavers being out of the labour force. The reduction of the posterior mean in Model 2 shows that the low performance of Finland can largely be ascribed to the fact that it has an unfavourable employment situation and an unfavourable composition of the population of school-leavers. After all, the deviation of Finland 
from the overall performance within the European Union almost disappears if one controls for these variables. The same applies to Ireland. In the case of the United Kingdom, however, the same characteristics do not seem to contribute a great deal to the deviation from the overall performance. Instead, the position of the United Kingdom is better explained by the fact that the United Kingdom does not have a dual system, considering the drop in the deviation in Model 5. However, there are other factors that cause the United Kingdom to have a relatively high proportion of school-leavers out of the labour force, given the fact that the posterior mean of the United Kingdom in Model 5 is still relatively large.

At the other side of the spectre, we can see that the relatively low proportions of school-leavers being out of the labour force in countries such as Luxembourg, the Netherlands, Austria, Germany and Denmark, is largely due to the presence of a dual system. The posterior means in these countries show a large difference between Models 2 and 5, that is after controlling for the existence of a dual system. In the case of Austria, Germany and Luxembourg, a favourable composition of the population of school-leavers and/or a favourable general employment situation also seem to play a role. In Denmark, the low proportion of school-leavers being out of the labour force can fully be explained by the existence of a dual system.

Figure 5.2

Cross-country performance with regard to being out of the labour force

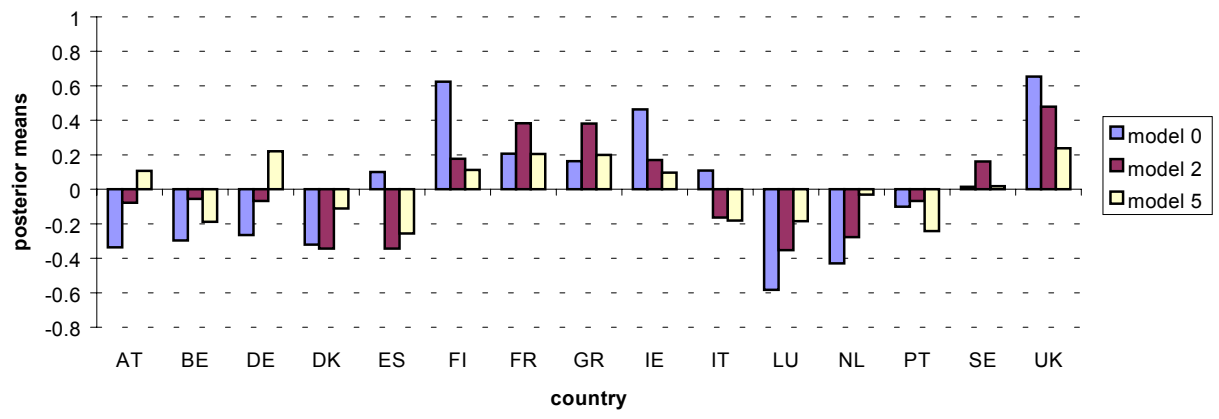

Source: pooled ECLFS-data 1992-1997

\subsection{Odds of being unemployed}

Table 5.4 displays the results of multilevel analysis with respect to the odds of being unemployed. Model 0 again gives the variation between the countries, without any control for other variables. The analysis shows that there are significant differences between countries in the odds of becoming unemployed (between-country variation is 0.640 ). There is also a significant variation within countries between the different time periods (0.019), but these differences are rather small compared to the systematic variation between countries. 
The introduction of individual characteristics in Model 1 shows that the odds of becoming unemployed is significantly affected by the personal background of schoolleavers. For recent school-leavers, the odds of being unemployed versus being employed is two times larger than the corresponding odds for less recent schoolleavers $\left(e^{0.712}=2.038\right)$. Those who have left education at the ISCED0-2 level also have unfavourable chances on the labour market. Their odds of being unemployed is 94 percent higher $\left(e^{0.665}=1.944\right)$ than the odds for the group of school-leavers who left education at the tertiary level (ISCED5-7). Those who left education at the intermediate level (ISCED3) hold an intermediate position. The figures show that women have higher chances of becoming unemployed than men. The implied odds ratio is $1.179\left(\mathrm{e}^{0.165}\right)$. In contrast to the analysis of being out of the labour force, none of the individual characteristics seem to have an effect on the differences in unemployment among youngsters between time periods or between countries. This indicates that these differences are related to other factors than compositional effects of the population of school-leavers in the different countries.

Not surprisingly, the most important of these other factors is the general labour market situation. After controlling for the aggregate unemployment rate in Model 2, the residual variance component decreases at the country level from 0.644 to 0.221 and at the period level from 0.023 to 0.002 . In other words, around two thirds of the systematic differences between countries and over 90 percent of the within-country variation can be statistically explained by differences in the general labour market situation. This means that the unemployment risk of school-leavers is primarily determined by general employment conditions, which also affect the rest of the labour force. Still, there are significant differences left, especially at the country level.

Model 3 shows that about half of these remaining differences between countries can be explained by the institutional arrangements in the labour market system. In countries that are characterised by a strong employment protection for the existing labour force, school-leavers have a much higher probability of being unemployed than in countries that are more open to newcomers. This corroborates hypothesis 3. The wage bargaining structure also has the hypothesised effect on the unemployment rate among school-leavers (see hypothesis 1). Countries characterised by a centralised/co-ordinated wage bargaining structure are more open for newcomers on the labour market than decentralised/unco-ordinated countries and, consequently, show lower unemployment rates among labour market entrants. There is no significant effect of specific youth measures taken, although the sign is in the expected direction, i.e. the more a country spends on specific youth measures, the lower the unemployment risk for school-leavers. However, the 'real' effect of youth measures may be hidden. As youth measures in general are taken only in the case of high youth unemployment rates, the effect may be counterbalanced by the unfavourable youth unemployment conditions. Finally, union density does not seem to have any effect at all on the odds of becoming unemployed for school-leavers. 


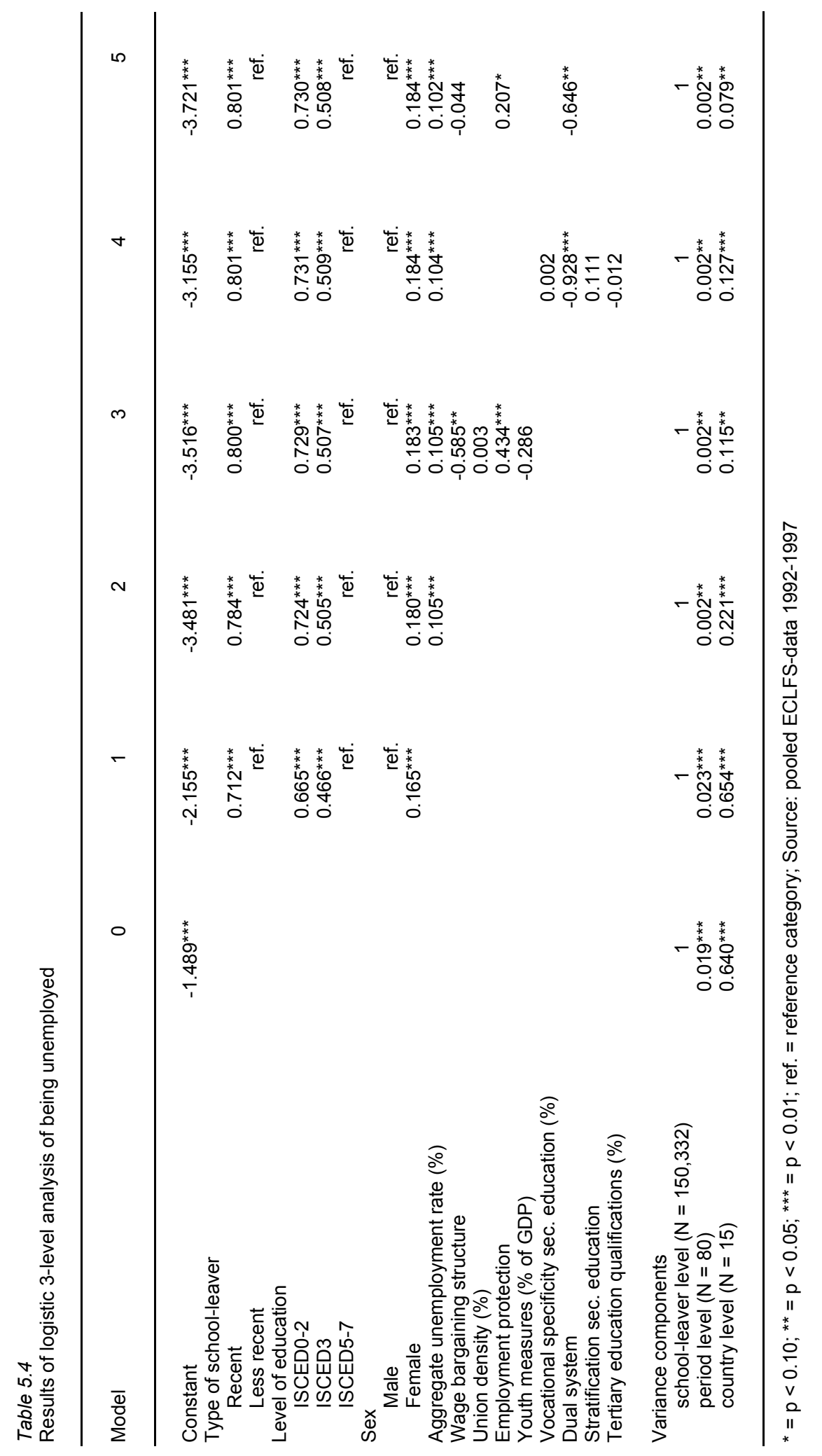


In Model 4, characteristics of the education and training system are included. The results are fairly straightforward. Countries with a dual system have lower unemployment rates among school-leavers than countries without a dual system. Again, this finding supports hypothesis 5. Also note again that the effect of the dual system on unemployment probabilities is not related to the vocational orientation of dual systems, but rather to the effect it has on the allocation of young people.

Model 5 integrates Models 3 and 4 by taking up only the significant variables of the two models. We can see that both types of factors have their own independent effect on the unemployment risk of school-leavers. Taken together, the three variables explain a large part of the residual variance in Model 2. In other words, the country differences in unemployment rates among youngsters can largely be explained by general differences in the labour market situation in these countries. Countries with a high aggregate unemployment rate also have a high unemployment rate among school-leavers. The remaining differences can be attributed to differences in institutional arrangements, namely employment protection, the wage bargaining structure and the existence of a dual system. Both the differences between countries and the differences within countries between the years can for almost 90 percent be explained by the variables in the model.

Figure 5.3

Cross-country performance with regard to being unemployed

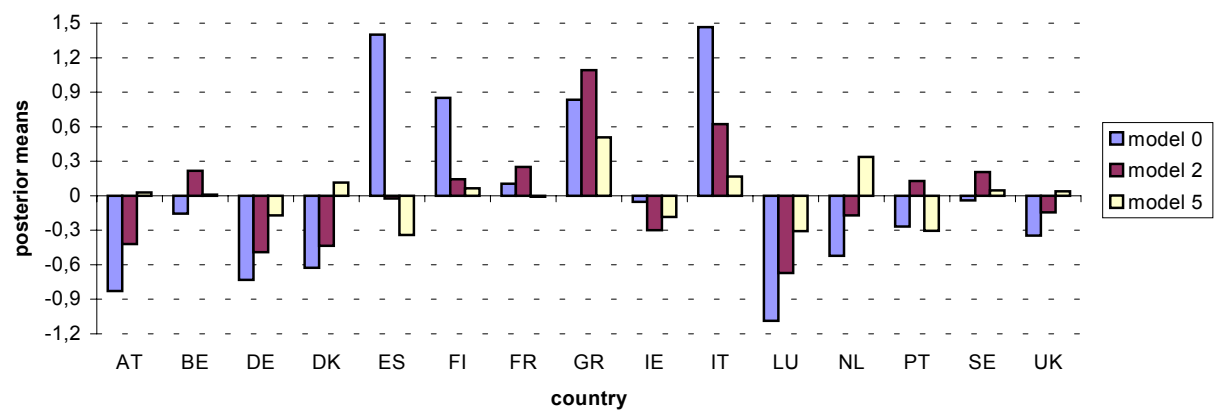

Source: pooled ECLFS-data 1992-1997

Figure 5.3 presents the posterior means again. The figure displays the performance score of each country as a deviation from the overall performance score within the European Union. It can immediately be seen that the deviations of the countries are almost fully explained by the variables in the model. The extremely high unemployment rate among school-leavers in Spain and Finland (see Model 0), for example, is fully explained by the aggregate unemployment level in both countries. Statistically controlled for that effect, unemployment among youngsters in Spain and Finland is about the same as the overall youth unemployment within the European Union (see Model 2). The same applies to Italy: the high unemployment rate for school-leavers in that country can fully be explained by an unfavourable general 
employment situation and by the national institutional context (high employment protection and the absence of a dual system). Greece seems to be a bit of an exception. The high unemployment rate among youngsters in that country can only partly be explained by the institutional factors in the model, given the fact that in Model 5 Greece still shows a relatively high unemployment among them.

Conversely, the low unemployment rates in countries such as Austria, Germany, Denmark, Luxembourg and the Netherlands, seem to be caused primarily by the existence of a dual system in these countries and furthermore by favourable general employment conditions. Denmark also profits from a low strictness of employment protection, while Austria and Germany seem to profit from the centralised/coordinated wage bargaining structure.

\subsection{Odds of having a temporary job}

Table 5.5 presents the results of the next analysis: the odds of having a temporary job. Model 0 again describes the variance between countries and within countries between the years. The variation between countries seems larger than in the previous analysis: 0.943 as against 0.640 with respect to the odds of being unemployed.

In Model 1 the individual characteristics are introduced in the analysis. The largest effect stems from the type of school-leaver. For recent school-leavers, the odds of having a temporary job is more than three times higher than for less recent schoolleavers $\left(\mathrm{e}^{1.145}\right)$. Furthermore, low educated school-leavers (ISCED0-2) are more often in temporary positions than high educated ones (ISCED5-7). The implied odds ratio is $1.428\left(\mathrm{e}^{0.356}\right)$. There is no effect of gender on the odds of having a temporary job. Both females and males run the same risk of having temporary work. None of these individual characteristics have any effect on the overall variation between countries.

Variation between countries with regard to the likelihood of school-leavers having a temporary job, is heavily affected by the differences in the overall employment situation (see Model 2). For each percentage of increase in a country's unemployment rate, the odds for school-leavers having a temporary job increase $1.048\left(\mathrm{e}^{0.047}\right)$. Almost half of the original between-country variation can be explained by differences in the unemployment situation of the different countries. Interestingly, the within-country variation does not appear to be affected by the aggregate unemployment level. The variation within a country between the different time periods was already very small (only 0.013 as compared to 0.943 for the betweencountry variation). Apparently, the variation over time is caused by other factors than the general labour market situation in a particular year.

In Model 3 the institutional characteristics of the employment system are introduced. As stated in hypothesis 3, in countries that are characterised by strict employment protection legislation, the likelihood of having a temporary job is higher than in countries with less strict employment protection legislation. The effects of two other 
institutional contexts with regard to the employment system (youth measures and the wage bargaining structure) also point in the expected direction, but these are not significant. Finally, there is no effect of trade union density. In total, the institutional factors regarding the employment system cause a drop in the between-country variation from 0.526 in Model 2 to 0.466 in Model 3. This implies a reduction of some 10 percent.

Model 4 introduces the impact of different institutional contexts of the education and training system. Although having a dual system in a country seem to lower the odds of having a temporary job for school-leavers, the difference is just insignificant ( $p>$ 0.10). The other characteristics do not seem to have any effect at all.

The last model (Model 5) includes only the significant effect of employment protection. The variables in the model explain about half of the original betweencountry variation. This means that there are still significant differences left unexplained. Figure 5.4 shows this for each country separately. In the figure, one can clearly see the huge differences in the gross performance between countries with regard to school-leavers having a temporary job. Spain and Finland have a very high score - indicating a relatively high proportion of temporary employment - and Luxembourg, on the other hand, a very low one. The figure also shows that the disadvantageous position of Spain can partly be ascribed to its bad labour market circumstances in general, as well as its high degree of employment protection. However, these factors do not explain the relatively high score of Finland, nor the relatively low score of Luxembourg. It seems that for some countries (the United Kingdom, Spain, Portugal and Denmark), the model does a good job in explaining the country's position, whereas for other countries (Belgium, Germany, Finland, France and Luxembourg) the model does not explain very well the proportion of school-leavers having a temporary job. In the case of Italy and Sweden, the model even enlarges the original differences, indicating that other factors in these two countries cause the country's specific position.

Figure 5.4

Cross-country performance with regard to having a temporary job

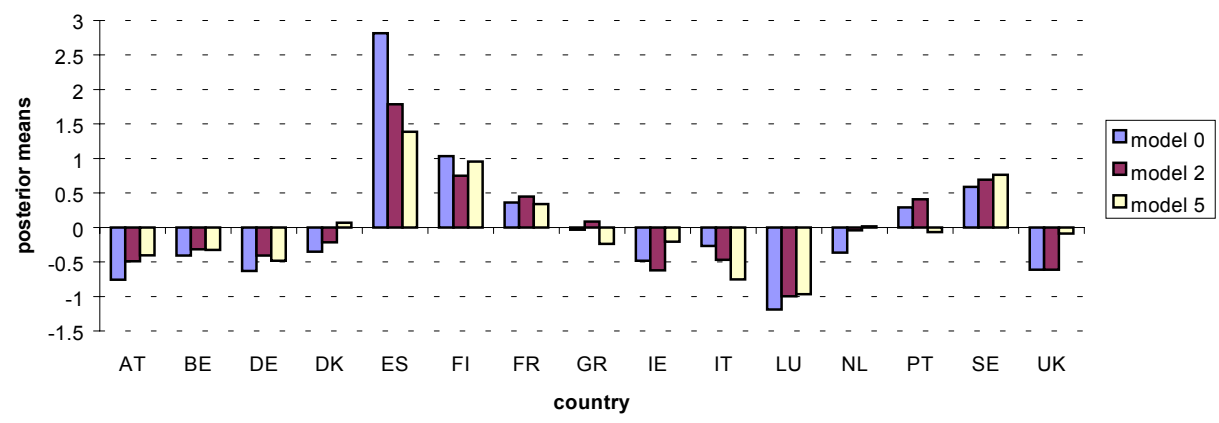

Source: pooled ECLFS-data 1992-1997 


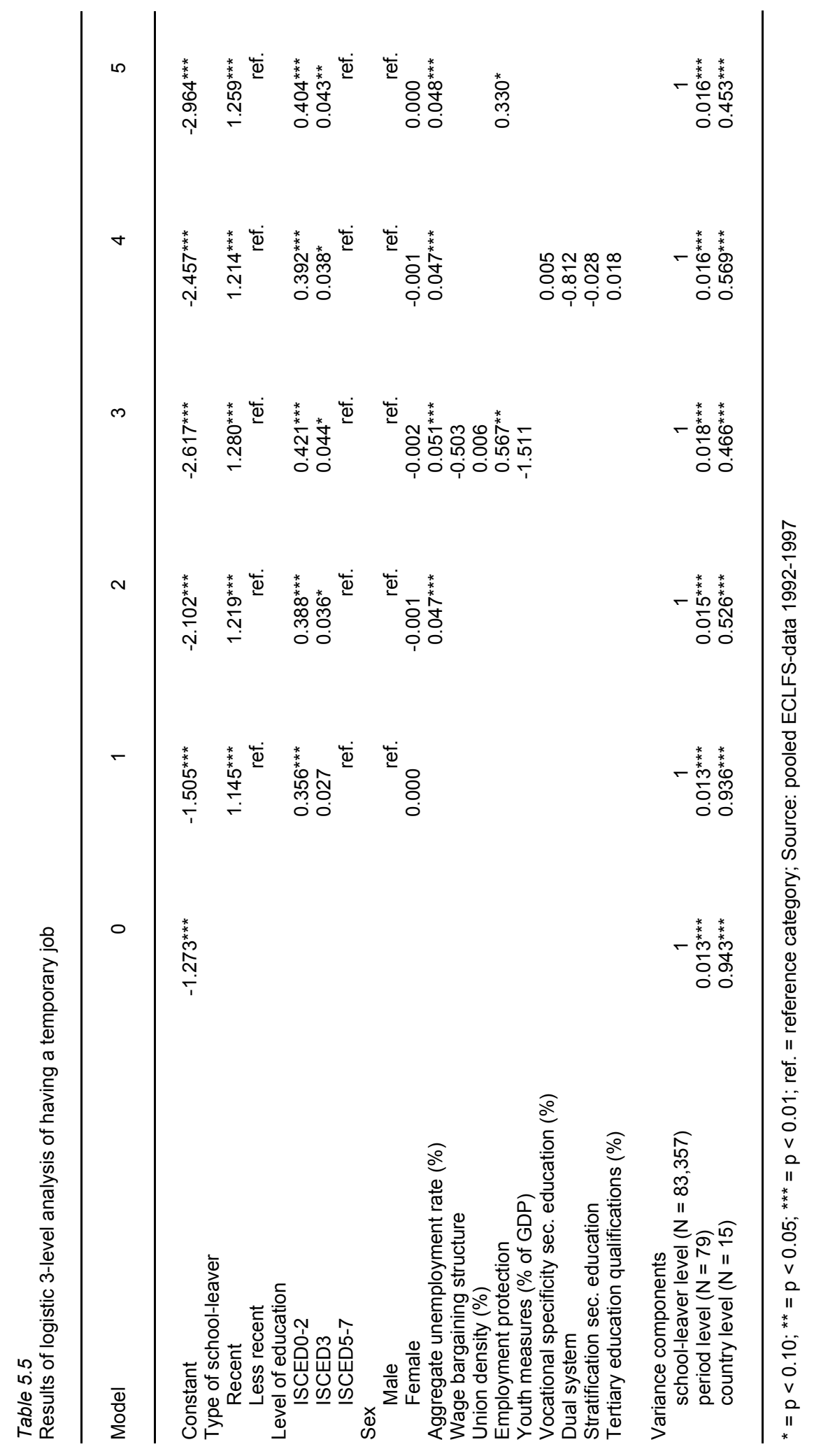




\subsection{Odds of having a part-time job}

The final analysis relates to the odds of school-leavers having a part-time job (see Table 5.6). Model 0 indicates that there are significant differences between the countries, as has already been described in Figure 4.4. The model also shows significant variation between the different time periods within a country, but this variation is small compared to the between-country variation $(0.027$ versus. 0.606$)$.

All individual characteristics in Model 1 have a significant effect on the odds of having a part-time job. Not surprisingly, female school-leavers have a much larger likelihood of having part-time work than their male counterparts. For women, the odds of having a part-time versus full-time job is three-and-a-half times higher than the corresponding odds for men $\left(e^{1.240}=3.456\right)$. Similarly, recent school-leavers run a two times larger risk of having part-time work than less recent school-leavers $\left(e^{0.732}=\right.$ 2.079). Finally, the level of education determines the individual chances of having part-time work: the higher the level of education, the lower the probability of having a part-time job.

The general employment situation in a country does not relate in any way to that country's proportion of school-leavers having part-time work (Model 2). The increase in the between-country variation between Model 1 and Model 2 indicates that adding the aggregate unemployment rate to the model even deteriorates the model fit.

In Model 3, where the institutional characteristics of the employment system are added to the model, the employment situation does have an effect on the country's proportion of school-leavers having a part-time job. Apparently the effect of the employment situation is correlated with institutional characteristics of the labour market.

Model 4 brings about a significant improvement of the model. This relates especially to the vocational specificity of secondary education and to the expansion of tertiary education. The more vocation-specific a country's secondary education is, the higher the proportion of school-leavers having part-time work. So, with respect to part-time employment hypothesis 5 has been falsified. In addition, the more the tertiary education system has expanded, the higher the overall proportion of part-time work in that country. This finding corroborates hypothesis 7 . Note, however, that this effect controls for the individual effect of level of education. For each individual, the odds of having part-time work is negatively correlated with his/her level of education. But the more individuals have attained tertiary education in a specific country, the higher the odds of having a part-time job for school-leavers in that country, regardless of their own level of education. 


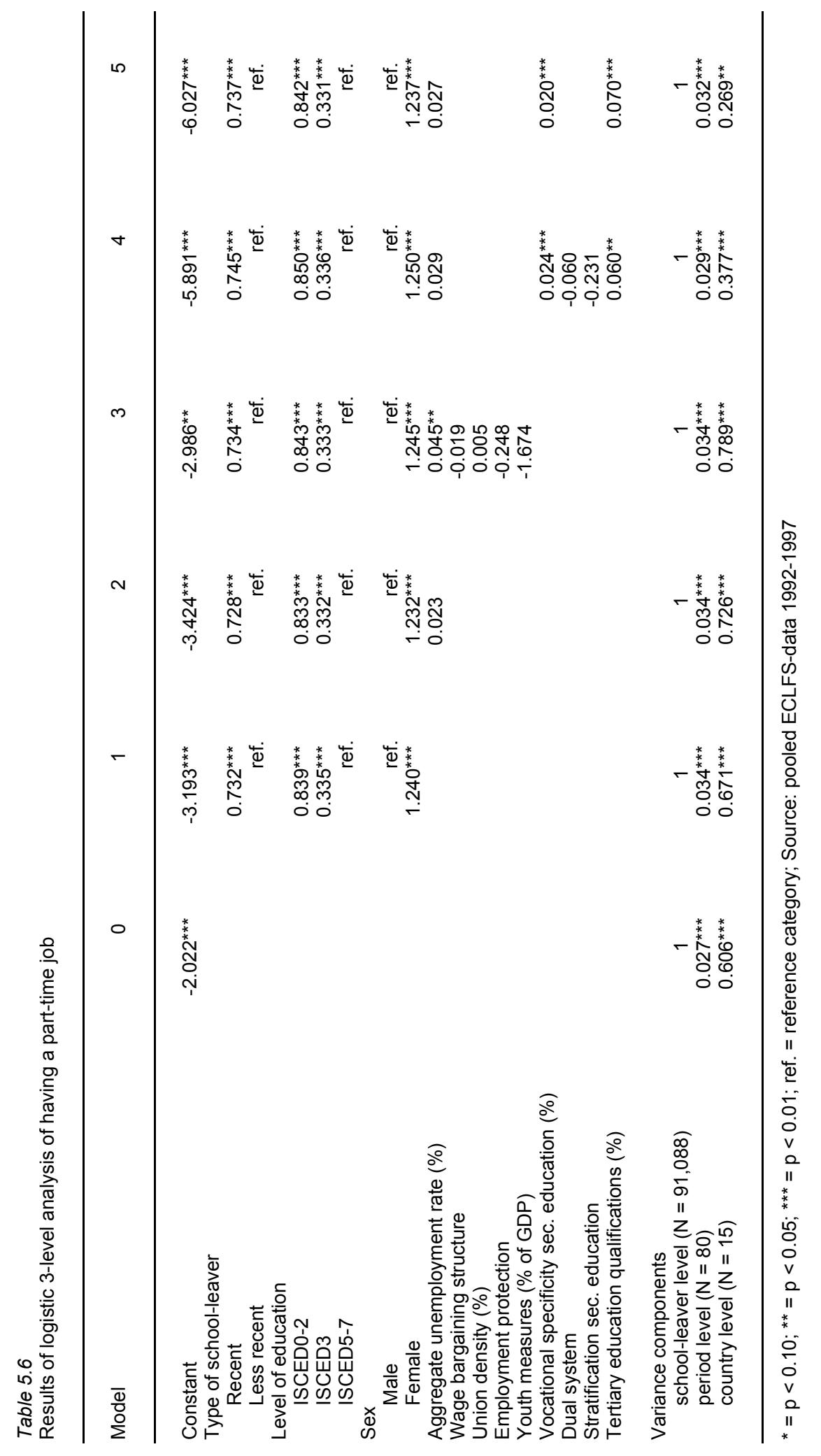


Introducing only the significant characteristics of the country's education system in the model (Model 5) explains about half of the original differences between the countries. Figure 5.5 displays the posterior means for each country in the Models 0,2 and 5. The figure clearly shows the large differences in the proportion of young people having part-time work between Sweden and the Netherlands on the one hand, and Luxembourg and Portugal on the other hand. It also shows that the posterior means in the countries do no change between Model 0 and Model 2, indicating that the differences between the countries cannot be explained by individual characteristics and the general labour market conditions. The educational characteristics of Model 5 do seem to explain the specific position of countries such as Sweden, Portugal, the Netherlands, Italy, Greece, Ireland, Belgium and Austria. However, these characteristics do not explain the position of some of the other countries, most notably Luxembourg, Spain and France. In these countries other factors cause the country-specific position with respect to the proportion of schoolleavers having part-time work.

Figure 5.5

Cross-country performance with regard to having a part-time job

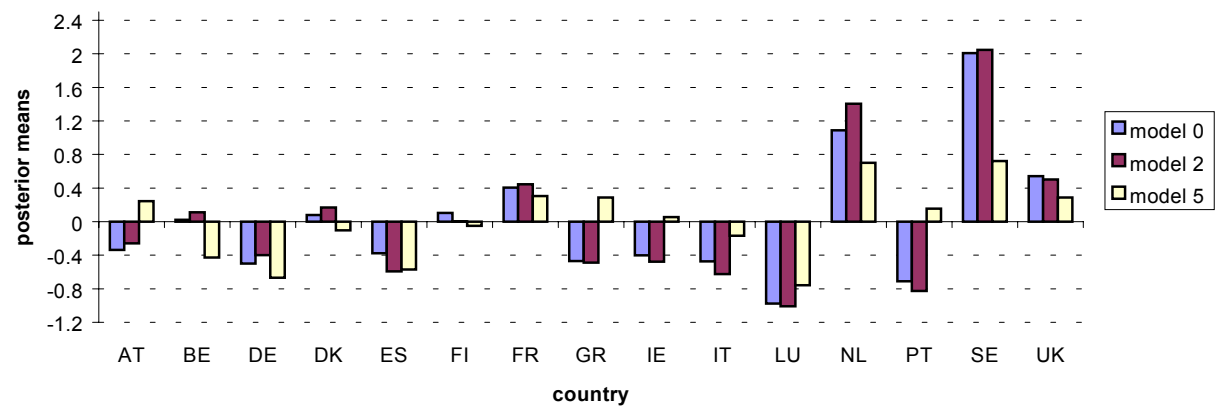

Source: pooled ECLFS-data 1992-1997 


\section{Conclusions and discussion}

In this study we investigated to what extent national institutional arrangements both with regard to the employment system and the education/training system affect the integration of young people into the labour market within the European Union. The aim was to determine differences in the integration process between countries and to relate this cross-country variation to differences in national institutional contexts. For this purpose, data of the European Community Labour Force Surveys (ECLFS) for the period 1992-1997 were used. This combined data set provides information about four important indicators that capture the (lack of) labour market integration of youngsters: the likelihood of being out of the labour force, being unemployed, having a temporary job and having a part-time job. To estimate systematic variation between countries adequately, we applied multilevel analysis to the data in which is statistically controlled for variation within countries between individuals and for variation within countries between years. A detailed overview of the results per country is presented in Table 6.1. Here, we mainly focus on those countries presenting extreme positions in the analysis.

The findings with regard to the likelihood of being out of the labour force show that there are substantial differences between countries. High proportions of inactivity among school-leavers can be found in the United Kingdom, Finland and Ireland; low proportions in the Netherlands, Luxembourg, Austria, Belgium, Germany, and Denmark. The characteristics under investigation explain about three quarters of the observed differences between the various countries. In Finland, for instance, the very large proportion of school-leavers being out of the labour force can for a great part be ascribed to the fact that this country has an unfavourable general employment situation. In the case of the United Kingdom, however, the labour market situation does not seem to contribute a great deal. Instead, the relatively disadvantageous position of the United Kingdom is better explained by the fact that it does not have a dual system. However, there are still other, not investigated factors that cause the United Kingdom to have a high proportion of the school-leavers out of the labour force. The relatively low proportions of school-leavers being out of the labour force in countries such as Luxembourg, the Netherlands, Austria, Germany, and Denmark, can largely be ascribed to the existence of substantial apprenticeship systems in these countries.

The likelihood of being unemployed also differs strongly between countries. High proportions of unemployment are found in Italy, Spain, Greece and Finland, whereas low unemployment rates are observed in Luxembourg, Austria, Germany, Denmark and the Netherlands. This cross-country variation in youth unemployment rates is almost fully explained by differences in the general labour market situation and varying institutional contexts with respect to employment protection, wage bargaining and the presence of a dual system. For example, the extremely high unemployment rates among school-leavers in Spain and Finland can be attributed entirely to the high general levels of unemployment in the two countries. The same applies to Italy: the high unemployment rate for school-leavers in that country can mainly be explained by an unfavourable general employment situation. Furthermore, high 
employment protection of the working labour force and the absence of a dual system hinder Italian school-leavers to find a job. Greece seems to have an exceptional position. Its high level of unemployment among school-leavers can only partly be explained by the institutional factors measured in this study. On the other hand, the low youth unemployment rates in the German surrounding countries seem to be caused primarily by the existence of an elaborated dual system, even after taking the favourable general employment conditions in these countries into account. Danish school-leavers also profit from a low strictness of employment protection. In Austria and Germany the centralised/co-ordinated wage bargaining structure also lowers the youth unemployment rate in both countries.

There are huge country differences in the performance with regard to school-leavers having a temporary job. Especially in Spain and, to a lesser extent, in Finland, school-leavers often start in a job with a temporary contract. In Luxembourg and Austria, on the other hand, the proportion of youngsters who are working on the temporary basis is very low. About half of the cross-country variation can be explained by the effects of the general labour market situation and the degree of employment protection of the existing labour force. So, the high proportion of temporary employment in Spain, for example, can basically be ascribed to its bad labour market circumstances in general and its high degree of employment protection. The other half can be explained by other, non-measured country characteristics.

Large differences with regard to the proportion of young people having part-time work are observed as well within the European Union. Sweden and the Netherlands have the highest rates of part-time employment. In Luxembourg and Portugal, on the other hand, only a few percent of all school-leavers work in a part-time job. The differences between the countries can neither be explained by individual characteristics, nor by general labour market conditions. Instead, two indicators reflecting the educational participation determine to a large extent the rate of part-time employment in a country. Firstly, it is found that the more youngsters follow a vocational programme in secondary education, the higher the proportion of school-leavers having part-time work. Secondly, we observed that the higher the attainment of tertiary education is, the higher the proportion of part-time employment among school-leavers. In some countries, however, these two educational characteristics do not explain their position within the European Union. In these countries, most notably Luxembourg, Spain, and France, other factors cause the country-specific performance with respect to the proportion of school-leavers having part-time work.

Overall, it can be concluded from these results that the labour market integration of young people within the European Union is indeed systematically structured by national institutional contexts. With regard to national institutional factors concerning labour market regulations, it is primarily the employment protection of the existing labour force that has a damaging effect on the integration process of youngsters. In countries with a less strict employment protection legislation, school-leavers find a (stable) labour market position more easily than in countries with a high strictness of employment protection. In addition, the wage bargaining structure plays a role, with 
centralised/co-ordinated systems performing better than decentralised/uncoordinated ones in terms of unemployment among school-leavers. These two findings confirm empirically the supposed insider-outsider dichotomy in the labour market. Unexpectedly, trade union power and active youth labour market policies do not have any effect on the integration process of youngsters into the labour market. The absence of an effect of active labour market policies does not imply that these policies are not effective. As the occurrence of these policies are also related to the severeness of youth unemployment in a specific country, the causal relation between the two is hard to disentangle.

With regard to institutional characteristics of education/training systems, it is clear that the presence of an extensive dual system - as a workplace-based vocational training system - improves the transition from school to work in a country. The positive effect of having a dual system on the labour market integration of youngsters stems from the strong allocation function of the dual system: the institutionalised pathway it provides for young people to enter the labour market. The effect does not seem so much to be related to the more vocational orientation of countries with a dual system, since the occupational specificity of vocational education does not play an important role in the integration process. The stratification of the education system neither has an impact on the transition from school to work.

Furthermore, it turned out that the indicators for the measurement of youth labour market integration show quite similar results and are, therefore, coherent key indicators. Only with respect to part-time employment it seems that this labour market outcome is a less appropriate indicator. First of all, the cross-county variation regarding part-time employment could not be explained by the factors that are - to a large extent - responsible for the country differences with respect to the other indicators. Part-time employment among young people in a country is neither influenced by the general labour market situation nor by the degree of employment protection legislation and/or the provision of a dual system in that country. In addition, part-time employment is hardly correlated at the country level with the other indicators for the integration of young people into the labour market, whereas these other indicators are fairly strong interrelated. In this study, part-time employment has only been considered in relation to young people only, while it would have been interesting to compare young people with more experienced workers in that respect. It might well be that a high percentage of part-time work in a country is not a characteristic of the youth labour market, but a more generalised feature of the labour market of that country.

Lastly, we should mention a certain limitation of this study. Due to the rather limited availability of adequate dependent variables in the data set used, we could not give a complete picture of the integration process of school-leavers into the labour market. Firstly, information on wages is lacking. Secondly, job match or skill use characteristics are missing. For instance, it was not possible to determine whether the actual level of education held by school-leavers fits with the level of education requested by the job ('overeducation'). Thirdly, information on labour mobility is not available. Since school-leavers often start in jobs that do not match their education, 
job mobility is considerable among school-leavers. Therefore, in future research it would be very interesting to investigate whether national institutional contexts affect these other indicators of youth labour market integration. However, this kind of information requires other comparative data sources that are unfortunately not available (yet). 


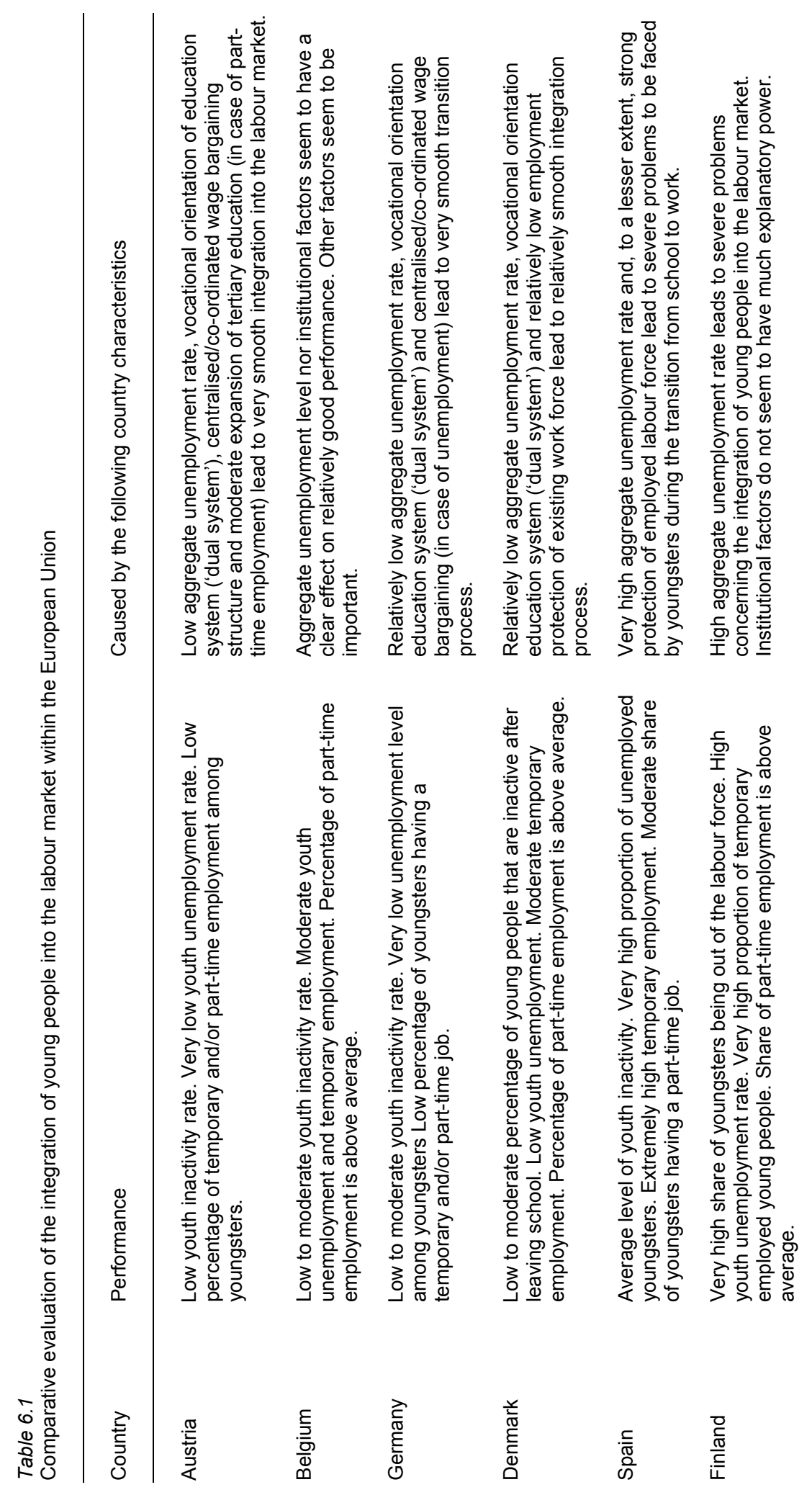




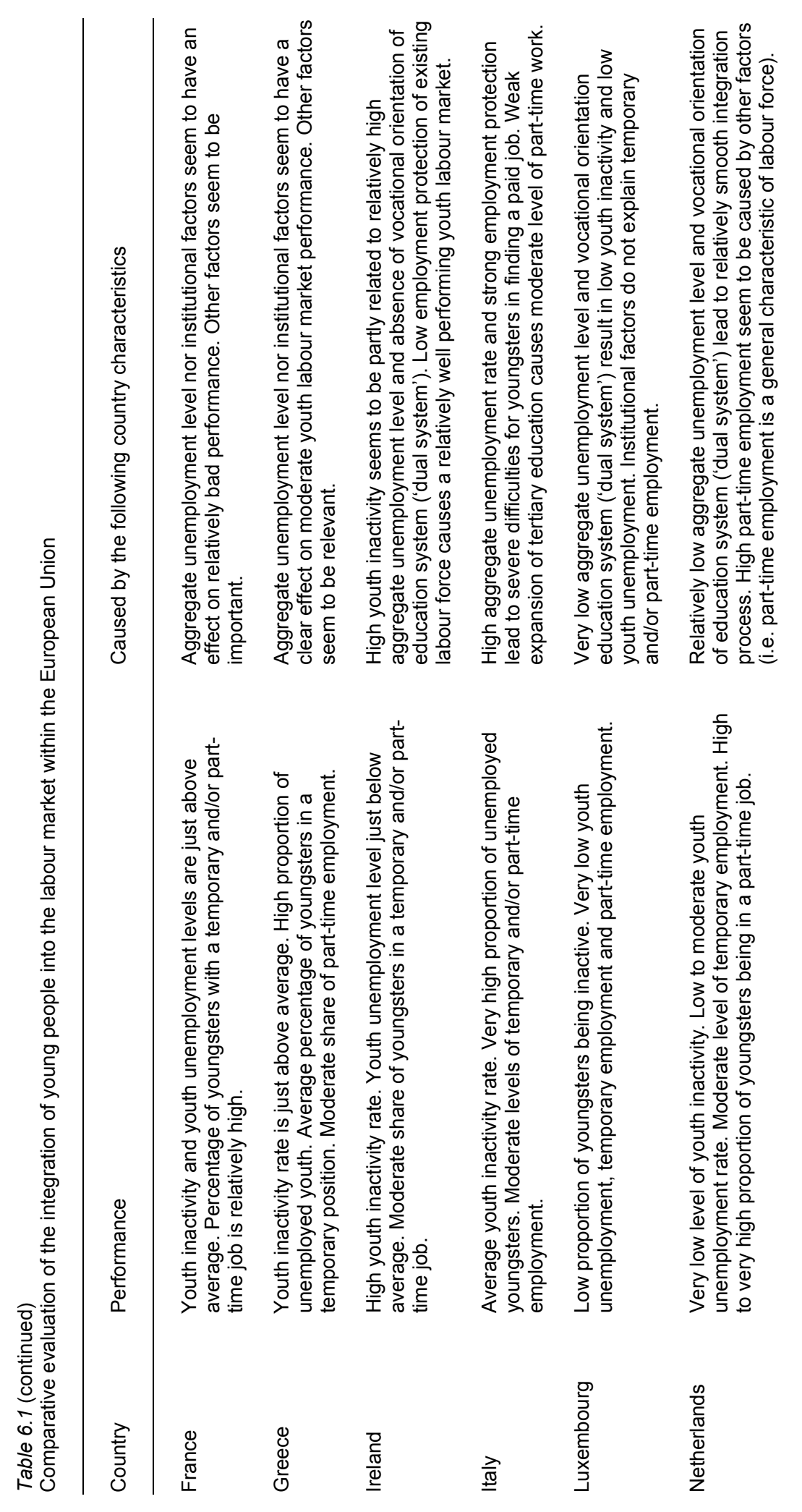




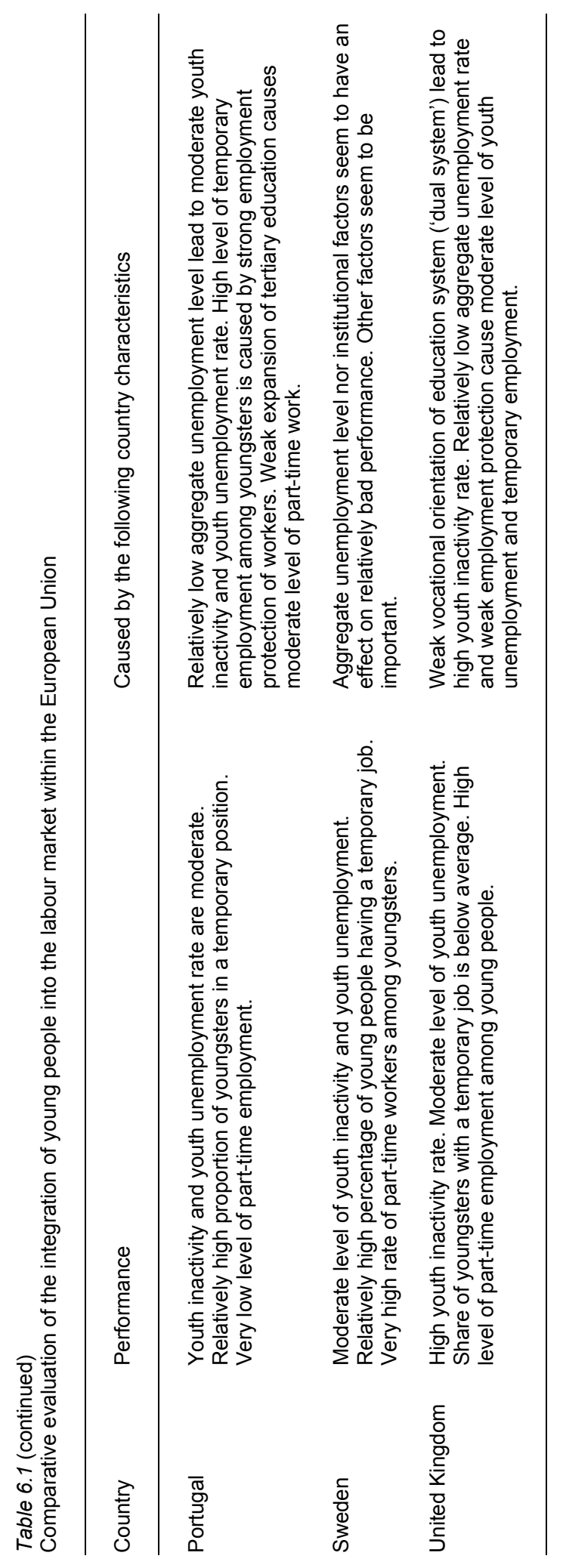





\section{References}

Allmendinger, J. (1989), Educational systems and labour market outcomes, European Sociological Review, vol. 5, pp. 231-250.

Bean, C. (1994), European unemployment. A survey, Journal of Economic Literature, vol. 32, pp. 573-619.

Boudon, R. (1974), Education, opportunity, and social inequality, New York: Wiley Press.

Brauns, H., Müller, W., and Steinmann, S. (1997), Educational expansion and returns to education. A comparative study on Germany, France, the United Kingdom and Hungary, MZES Working Paper AB I/23, Mannheim: MZES.

Bryk, A., and Raudenbush, S. (1992), Hierarchical linear models, Newbury Park: Sage.

Calmfors, L., and Driffill, J. (1988), Bargaining structure, corporatism and macroeconomic performance, Economic Policy, vol. 6, pp. 13-61.

Calmfors, L. (1994), Active labour market policy and unemployment. A framework for the analysis of crucial design features, OECD Economic Studies, no. 22. Paris: OECD.

Commission of the European Communities (1993), Growth, competitiveness, employment. The challenges and ways forward in the 21st century, White Paper, 6/93, OPCE.

Denison, E. (1962), The sources of economic growth in the United States and the alternatives before us, New York: Committee for Economic Development.

Devine, T., and Kiefer, N. (1991), Empirical labor economics, Oxford: Oxford University Press.

DeVreyer, Ph., Layte, R., Wolbers, M. and Hussain, A. (2000), The permanent effects of labour market entry in times of high unemployment, in: D. Gallie and S. Paugam (eds.), Welfare regimes and the experience of unemployment in Europe, pp. 134-152 Oxford: Oxford University Press.

Ebbinghaus, B., and Visser, J. (1999), When institutions matter. Union growth and decline in Western Europe, 1950-1995, European Sociological Review, vol. 15, pp. 135-158.

Gangl, M., and Brauns, H. (1999), The educational stratification of labour market entry: an analysis of structure and trends across the European Union, in: W. Müller et al. (eds.), $A$ comparative analysis of transitions from education to work in Europe - Based on the European Community Labour Force Survey, pp. 165-206, Mannheim, Maastricht, Marseille: MZES/ROA/CEREQ.

Goldstein, H. (1995), Multi-level statistical models, London: Edward Arnold.

Hannan, D., Raffe, D., and Smyth, E. (1997), Cross-national research on school to work transitions. An analytical framework, in: P. Werquin, R. Breen and J. Planas (eds.), Youth transitions in Europe: theory and evidence, pp. 409-442. Proceedings of third ESF workshop of the Network on Transitions in Youth, La Ciotat, September 1996, Marseille: CEREQ

Hannan, D., and Werquin, P. (1999), Education and labour market change. The dynamics of education to work transitions in Europe, paper presented at 'The European Socio-Economic Research Conference', Brussels, pp. 28-30, April 1999.

Hannan, D., et al. (1999), A comparative analysis of transitions from education to work in Europe (CATEWE), [Volume 1: A conceptual framework / demographic and economic changes], ESRI Working Paper 118(a), Dublin: ESRI.

ILO (1990), Statistical sources and methods, [Volume 3: Economically active population, employment, unemployment and hours of work (household surveys), second edition], Geneva: ILO.

Kerckhoff, A. (1995), Institutional arrangements and stratification processes in industrial societies, Annual Review of Sociology, vol. 15, pp. 323-347.

Layard, R., and Nickell, S. (1986), Unemployment in Britain, Economica, vol. 53, S121-S169.

Layard, R., Nickell, S., and Jackman, R. (1991), Unemployment, macroeconomic performance and the labour market, Oxford: Oxford University Press. 
Lindbeck, A, and Snower, D. (1988), The insider-outsider theory of employment and unemployment, Cambridge, Mass.: MIT Press.

Longford, N. (1993), Random coefficient models, Oxford: Clarendon Press.

Maurice, M., Sellier, F., and Silvestre, J.J. (1982), Politique d'éducation et d'organisation industrielle en France et en Allemagne. Essai d'analyse sociétal, Paris: Presses Universitaires de France.

Müller, W., and Shavit, Y. (1998), The institutional embeddedness of the stratification process. A comparative study of qualifications and occupations in thirteen countries, in: Y.Shavit and W. Müller (eds.), From school to work. A comparative study of educational qualifications and occupational destinations, pp. 1-48, Oxford: Clarendon Press.

Müller, W., and Wolbers, M. (1999), Educational attainment of young people in the European Union: cross-country variation of trends over time, in: W. Müller et al. (eds.), A comparative analysis of transitions from education to work in Europe - Based on the European Community Labour Force Survey, pp. 19-56, Mannheim, Maastricht, Marseille: MZES/ROA/CEREQ.

Nickell, S., and Layard, R. (1997), Labour market institutions and economic performance, Centre for Economic Performance and Statistics, Oxford University, Discussion Papers Series no. 23

OECD (1995), Education at a glance, Paris: OECD.

OECD (1996), Employment Outlook, Paris: OECD.

OECD (1997), Employment Outlook, Paris: OECD.

OECD (1998), Employment Outlook, Paris: OECD.

OECD (1999), Employment Outlook, Paris: OECD.

Oswald, A. (1987), Efficient contracts are on the labour demand curve: theory and facts, London School of Economics Centre for Labour Economics, Discussion Paper no. 284.

Ryan, P. (2001), The school-to-work transition. A cross-national perspective, Journal of Economic Literature, vol. 39, pp. 34-92.

Shavit, Y., and Blossfeld, H.P. (eds.) (1993), Persistent inequality. A comparative analysis of educational stratification in thirteen countries, Boulder: Westview Press.

Soskice, D. (1990), Wage determination: the changing role of institutions in advanced industrialised countries, Oxford Review of Economic Policy, vol. 6, pp. 36-61.

Sprengers, M. (1992), Explaining unemployment duration. An integrative approach, Utrecht: Ph.D. Dissertation Utrecht University.

Thurow, L. (1975), Generating inequality, New York: Basic Books.

Tuynman, A. and Potslethwaite, T. (eds.) (1994), Monitoring the standards of education. Papers. Honor of J.P. Keeves, Oxford: Pergamon Press.

UNESCO (1975), International Standard Classification of Education (ISCED), Paris: United Nations Educational, Scientific and Cultural Organisation.

Vishwanath, T. (1989), Job search, stigma effect, and escape rate from unemployment, in: Journal of Labor Economics, vol. 7, pp. 487-502.

Welters, R., and Wolbers, M. (1999), Learning and working. Double statuses in youth transitions within the European Union, in: W. Müller et al. (eds.), A comparative analysis of transitions from education to work in Europe - Based on the European Community Labour Force Survey, pp. 99-128, Mannheim, Maastricht, Marseille: report to the European Commission.

Wolbers, M., Graaf, D. de, and Ultee, W. (2001), Trends in the occupational returns to educational credentials in the Dutch labor market: changes in structures and in the association?, Acta Sociologica, vol. 44, pp. 5-19.

Wolbers, M. (2000), The effects of level of education on mobility between employment and unemployment in the Netherlands, European Sociological Review, vol. 16, pp. 185-200. 


\section{Appendix: the interpretation of posterior means}

Suppose that we have a group of three countries and that we are interested in the proportion of temporarily employed school-leavers in these countries. In Country A, temporary employment among school-leavers is 30 percent; in Country B 10 percent and in Country C 5 percent. Furthermore, the overall level of temporary employment in these three countries is 15 percent. The gross performance of each country, in terms of posterior means, can be expressed as the predicted percentage difference for this country from the overall percentage of temporarily employed school-leavers (see Model 0 in Figure A.1). So, in Country A the posterior mean is $30-15=15$. In Country $B$ this value is -5 and in Country $C$ it is -10 . In other words, a posterior mean is a relative performance measure that reflects the performance of a country in relation to the average performance of all countries.

Figure A.1

Example of cross-country performance with regard to having a temporary job

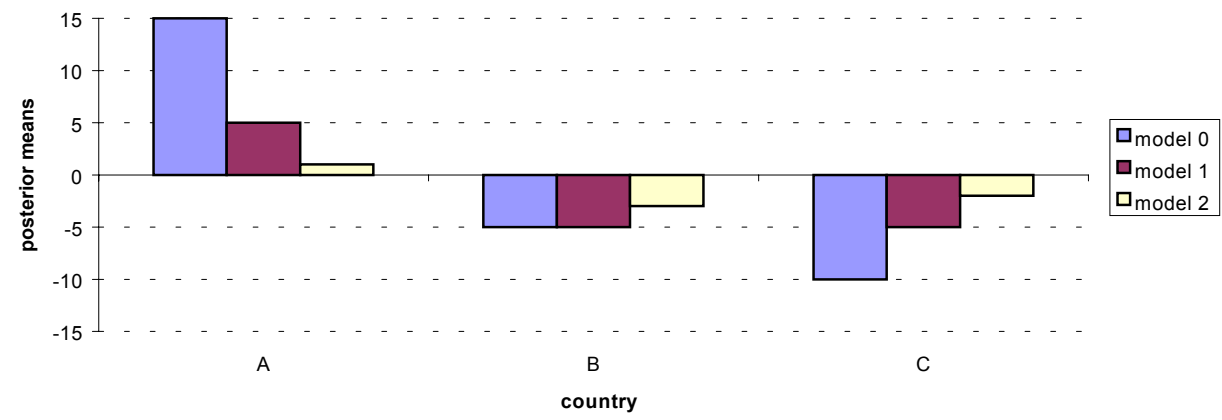

Suppose next that the general labour market situation is good in Country $C$ and bad in Country A. The labour market situation in Country B takes an intermediate position. The interesting question then is to investigate to what extent the observed cross-country variation in temporary employment among school-leavers (i.e. Model 0 ) can be ascribed to these differences in the general labour market situation. In other words, what we want to know is how the three countries differ in their performance with regard to temporary employment if we were in the fictitious situation that the general labour market situation in these countries is the same. Statistically speaking, we need to control in the analysis for the differences in the general labour market situation between countries and see to what extent the crosscountry variation in temporary employment can be reduced (or statistically explained) by including this variable in the analysis. Model 1 of Figure A.1 displays the posterior means, obtained after taking the effect of the general labour market situation into account. It can be concluded from this model that the variation across countries has decreased, since the original variation (simply measured as the absolute difference between the highest and lowest performance score) was $25(15+10)$ percent in Model 0 and 10 percent in Model 1 . This result indicates that the general labour 
market situation in a country affects indeed the proportion of temporary employment in that country. For Country $A$, the posterior mean now takes the value 5 , which means a reduction of 10 percentage points $(15-5=10)$. This finding implies that two thirds of the original low performance of Country A can be explained by its bad labour market situation. In other words, school-leavers of this country hold a temporary job relatively often, because the overall labour market situation in Country $A$ is so bad. For Country $\mathrm{C}$ a similar, but opposite interpretation is valid. The original performance score declines from -10 to -5 , indicating that half of the advantageous position of this country can be attributed to its good labour market situation. For Country $B$, the posterior mean has not changed at all. This result can be interpreted as an indication that the general labour market situation of this country equals the average labour market situation of all three countries, and therefore it has no effect on its relative performance with regard to temporary employment.

Model 2 of Figure A.1 shows the posterior means of the analysis in which, besides the general labour market situation of a country, the degree of vocational specificity of the education system is statistically controlled for. For this example, we assume that the vocational orientation of the education system is high in Country $C$ and low in Country A. Again, Country B takes a position in the middle. In fact, the performance scores displayed in this model reflect the country differences in temporary employment in the case of an equal labour market situation and an equally strong vocational specificity of the education system in all three countries. We see that the cross-country variation further decreases, indicating that differences in the vocational specificity of education systems explain to some extent differences in performance with regard to temporary employment, ceteris paribus. Moreover, it can be concluded from Model 2 that the ranking of the countries has changed. This can be explained as follows. A part of the bad performance of Country A must be attributed to its low vocational orientation of the education system. For Country $C$ the reverse is true: part of this country's good performance must be explained by the high vocational orientation of its education system. For Country B this also is true, but since in this country the vocational orientation of the education system is less strong than in Country $\mathrm{C}$, the 'net' performance is better. In a situation of equal labour market conditions and equally strong vocational orientation of education systems, Country $B$ would perform better (i.e. has a smaller proportion of school-leavers being in a temporary job) than Country $\mathrm{C}$.

How can we interpret the results of this example for benchmarking or policy-making? The basic message is simply that gross performance is not the same as net performance. Normally, we would look at gross outcomes and conclude that Country $\mathrm{C}$ has the best performance and Country A the worst. However, this does not tell us anything about the factors behind these differences. Do they have to do with differences in the general labour market situation of the country, or with institutional differences such as the vocational orientation of the education system? The methodological approach followed here enables us to conclude that a large part of the differences between the countries are explained by differences in the general labour market situation. More important for policy-making, however, is the finding that the vocational orientation of the education system affects the performance of a 
country. The policy implication based on this example would be to enlarge the vocational orientation of the education system. In terms of benchmarking, Country $B$ seems an interesting case, more interesting at least than Country C. After all, the performance of Country B is better than would be predicted on the basis of its general labour market situation and the vocational orientation of its education system. The implication is that there is something else to be learnt from Country $B$. 
